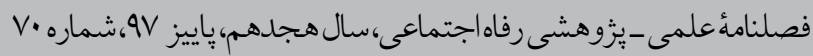

Social Welfare Quarterly, Vol 18, Fall 2018, No 70

سياستهاى فراتير رفاه خانواده در /يران

Universal Family Welfare Policies in Iran

مقلدم: در جوامع امروزى خانو/ده، بهعنوان عامل و ذئنع توسعه ديله مىشود و لنا سياست كذار/ن و برنامهريز/ن، كليه تصميمات و /قدامات خود

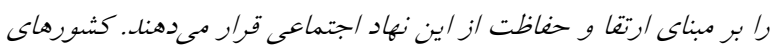
مختلف سياستها و خطمشيهاى مختلفى درزمينه سياست خذارى براى خانو/ده دارنا كه براى نمونه متىوان به تغاوت ديدكاه ميان همخانىبودن

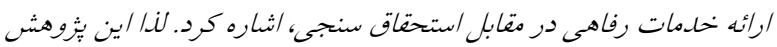

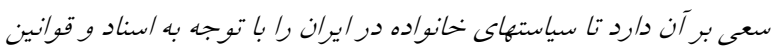

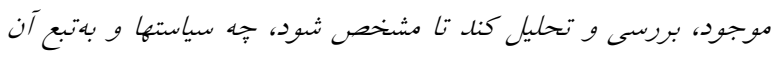
خحاتى براى عموم خانوادهها تلدوين و برنامهريزى شاده است.

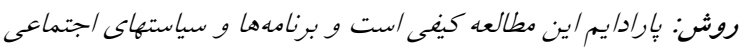

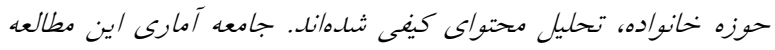

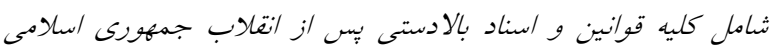

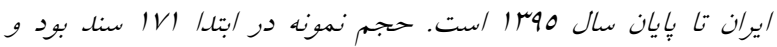

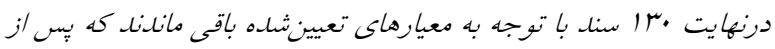

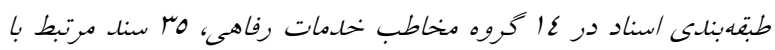

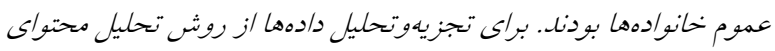

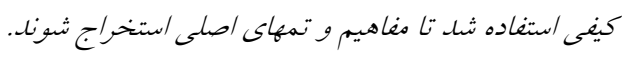

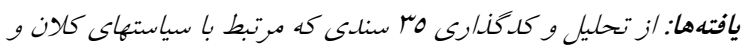

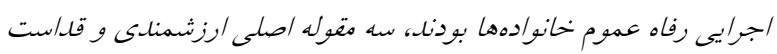

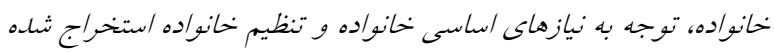

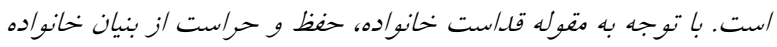

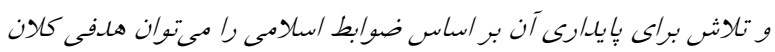

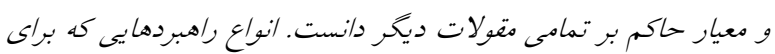

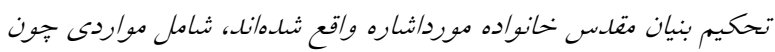

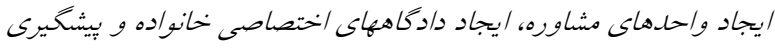

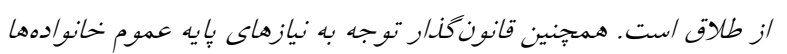

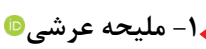

دكتر ملددكارى اجتماعى، مركز

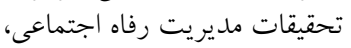

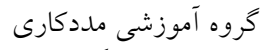
اجتماعى، دانشخاه علوم بهزيستى ماردي و توانبخشى، تهران، ايران.

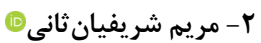

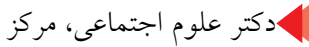
تحقيقات مديريت رفاه اجتماعى، اجتماعى مركي،

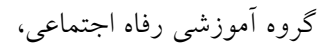
دانشخاه علوم بهزيستى و وزئن رفاه

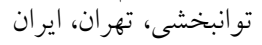

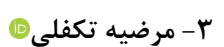
حانشجوى دكترى مددكارى اجتماعى، مركز تحقيقات

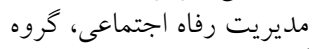
آموزشى رفاه اجتماعى، دانشياه

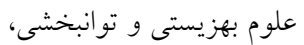

ايران.(نويسنده مسئول) تونئن <marzieh.takaffoli@gmail. com> 
را در حوزههاى بهه/شت و سلامت، بيمه، مسكن، /قتصاد و درآما و /منيت ملنظر قرار داده /ست كه در /سناد

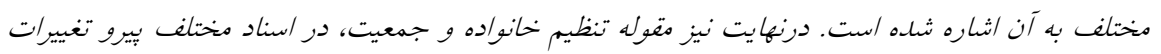

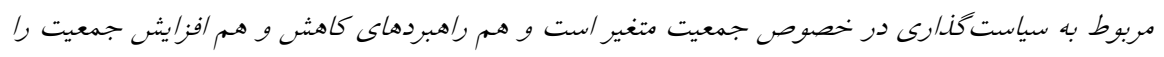
شامل مىشود. بحث: با توجه به يافته هاى حاصلى /ز تحليل اسناد و قوانين مىتوان عنوان كرد كه سياستهاى رفاه خانواده

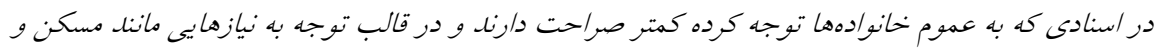

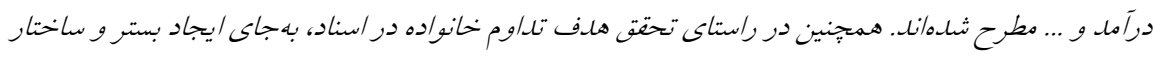

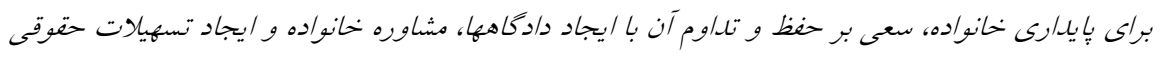

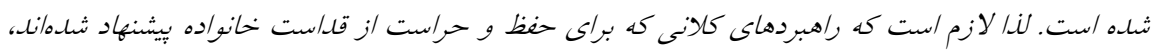

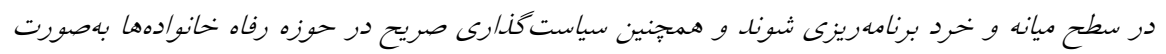

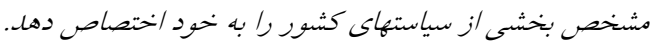

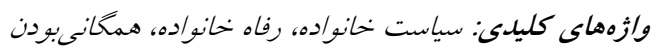

تاريخ دريافت: وارهاي كليدي: سلاست تاريخ بذيرش: وV/V/9 


\section{Universal Family Welfare Policies in Iran}

1-Maliheh Arshi

Ph.D in Social work, Academic member, University of Social Welfare and Rehabilitation Sciences, Social Welfare Management Research Centre, Department of Social Work, Tehran, Iran.

2- Maryam Sharifian Sani $\odot$ Ph.D in Social sciences, Academic member, University of Social Welfare and Rehabilitation Sciences, Social Welfare Management Research Centre, Department of Social Work, Tehran, Iran.

3- Marzieh Takaffoli $\odot$ Ph.D student in Social Work, University of Social Welfare and Rehabilitation Sciences, Social Welfare Management Research Centre, Department of Social Work, Tehran, Iran, (corresponding author)

$<$ marzieh.takaffoli@ gmail.com>
Introduction:Nowadays in societies, families are seen as agents and beneficiaries of development, and therefore policymakers and planners make all of their decisions and take necessary actions based on the promotion and protection of this social institution. Different countries have different policies in the field of family policies, such as in the terms of the universal approach vs. meantested one to the provision of welfare services. Therefore, this research aims to analyze family policies in Iran according to existing documents and laws, in order to determine which policies, and consequently, services are planned for families universally.

Method: The paradigm of this study is qualitative, that is, the social policies and laws about family have been analyzed qualitatively. The study population includes all laws and legislations of Iran since the Islamic Revolution (1979). It should be noted that the laws and legislations that have been approved before February 1979 would also have been considered as study population if they had still been valid. All laws and legislations which have been approved by the end of March 2017 were reviewed and analyzed. The sample size was initially 171 documents, in the end, 130 documents remained according to established criteria (1- The family is addressed directly in the title or goals of the law; in fact, preservation, promotion or health of the family are some goals of these laws; and 2- It is mentioned directly that the law is for the individual and his or her family, or seeing the person in the context of the family, such as being a spouse and mother, or considering the family relations, such as 


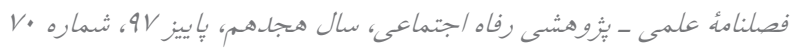

Social Welfare Quarterly, Vol 18, Fall 2018, No 70

child custody and marriage). After classification of documents in 14 welfare service user groups, 35 documents were found to be related to the universal family policies. The qualitative content analysis method was used to analyze the data so that the main concepts and themes were extracted.

Findings: According to analysis and coding of 35 policies and laws related to families, three main themes of sanctity of the family, addressing the basic needs of the family, and reproduction of family have been extracted. Most of the laws refer to the family as a worthwhile and sacred unit. The goal of most of these laws is to strengthen and assure sustainability of the family. Some of them specifically address family stability and divorce by establishing counseling systems, special family courts, and prevention of divorce. In some of the laws, the responsibility of family protection is provided by the family with strategies of nurturing and providing the children's emotional needs and promoting the interaction of the husband and wife. Finally, the three macro policies refer to the family-centered laws and policies. Considering the importance of this concept, the preservation and protection of the family can be considered as a great goal and criterion governing all the other categories in different levels of policy making and legislation. According to the second category, the legislator has also taken account of the basic needs of the all families in five areas of health (such as family physician program), insurance (all the family members' insurance), housing (such as considering housing as a right and priority to provide housing for low-income families), economics and income (such as paying attention to family poverty, Economic Development Program and Subsidies Targeting Program), and security (general and limited use of this term). Finally, the issue of reproduction of family and population, in various documents, varies according to changes in population policy-making, and includes both reducing and increasing population growth and in fact the purpose of these documents is the population, which can be regarded as a top priority.

Discussion: Considering the results of analysis of laws, it can be stated that family welfare policies are less explicit in documents that are for of all families and mostly addressed the needs, such as housing and income. Although in this study the policies and laws for general population of families have been extracted and analyzed, in many of these documents, there is not a universal approach to family. In many of addressed needs, the terms, such as vulnerable, unemployed, and so on could be seen. Thus it can 
be concluded that there is a pathological and mean-tested approach to family welfare in Iran. According to the study, family-centered laws and policies have been mentioned in limited documents which is in contrast to a significant number of documents mentioning sanctity of the family. The operationalization of this family-centering has not been mentioned either, and it is limited to overall and macro recommendations. It seems that the goal of maintaining and sustaining a family is predestinarian, in fact instead of developing a context for family sustainability, efforts have been made to preserve and sustain it by establishing specialized courts, family counseling, and legal facilities. The strategies proposed to protect the family's sanctity are macro strategies that need to be planned in operational levels. Finally, it could be concluded that explicit policies in the area of family welfare have to become a specific part of Iran policies. Besides, universal services should be defined and, of course, for vulnerable families, some specific policies and services should be considered in further studies since they were not addressed in this article. In fact, family-centered laws can help reducing family risks and even influences of other policies on family, such as the economy.

Keywords: Family policy, Family welfare, Universality

مقام

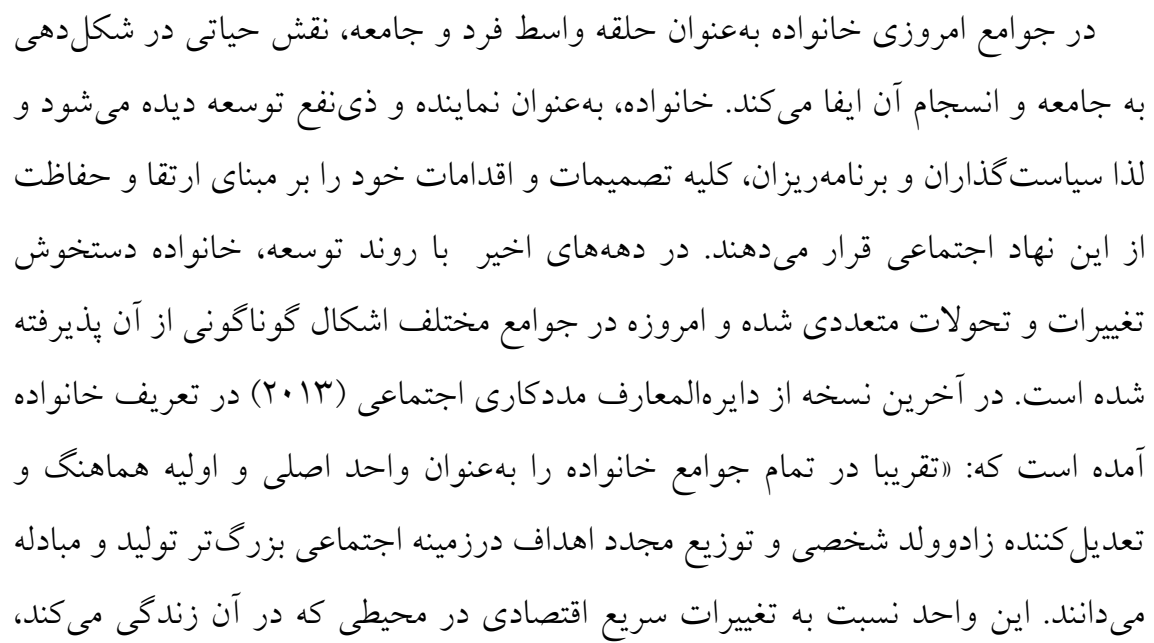


Social Welfare Quarterly, Vol 18, Fall 2018, No 70

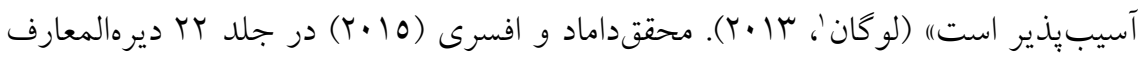
بزرگ اسلامى در تعريف خانواده آوردهاند: (اخانواده در قانون مدنى و ديخر قوانين ايران تعريف نشده است. حقوقدانان با توجه به قوانين و مقررات مربوط به آن، يك معناى عام (كسترده) و يك معناى خاص (محدود) براى خانو اده، لحاظ كردهاند. خانو اده به معناى عام خود، شامل شخص، خويشان نسبى و همسر او است (به نقل از كاتوزيان، IMVV صفايى، ع.(Y). ضابطه اين تعريف، همان ارثبرى افراد از يكديخر است (قانون مدنى، مواد

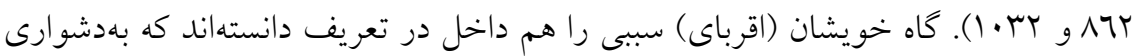
مىتوان خانواده بدين معنى را يك نهاد حقوقى فرض كرد؛ زيرا اخرجهه خويشاوندى سببى، يارهاى از آثار حقوقى براى شخص ايجاد مى كند، بالينهمه، بين خويشان نسبى و سببى هيج ضابطه و رابطه حقوقى وجود ندارد كه آنان را به يكديخر بيوند دهد و از آنان گروه واحدى بسازد. خانواده در معناى خاص خود، عبارت از شوهر، زن و فرزندان آنهاست. ماده 0 . قانون ملنى كه رياست خانواده در روابط زوجين را از خصايص شوهر دانسته، همين معنى

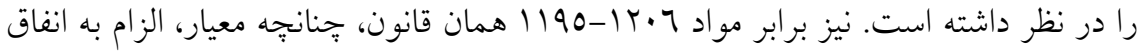
باشد، آنخاه به نظر مى آيد كه خانواده شامل شخص و زوجه و خويشان نسبى خط مستقيم

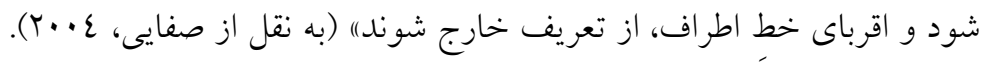
كشورهاى مختلف از نظر برخوردار بودن از سياستها و خطمشيهاى روشن درزمينه خانواده وضعيت يكسانى ندارند. در بسيارى از كشورها، درحالى كه درزمينه آموزش، بهداشت، تأمين اجتماعى، اشتغال، ماليات، مهاجرت و حقوق شهروندى قوانين و سياستهاى روشنى وجود دارد، در مورد خانواده، وضعيت اين گونه نيست. با همه اينها، اين اعتقاد وجود دارد كه رابطه بين زندگى خانوادگى و ارزشها و سياستهاى اجتماعى، رابطهاى دوطرفه است بهطورى كه هريك از آنها تأثيرات خاصى بر ديخرى خواهد داشت. در همين راستا، اختلاف نظرهاى زيادى درزمينه 
مطلوبيت رابطه بين خانو اده، دولت و نهاد اقتصادى جامعه وجود داشته و دارد. اينكه براى رسيدن به وضعيت مطلوبيت هريك از اين نهادها بايد جهه نوع ارتباطى با ساير نهادها داشته ونه

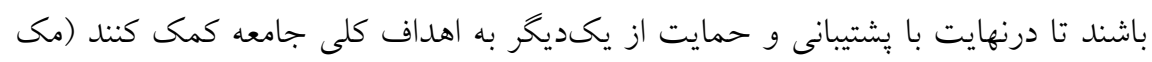

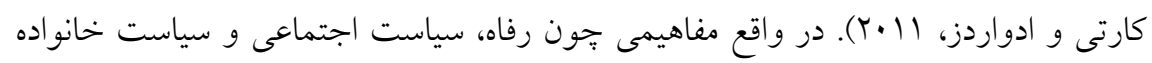

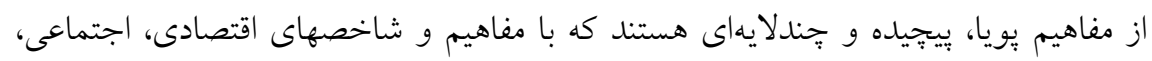

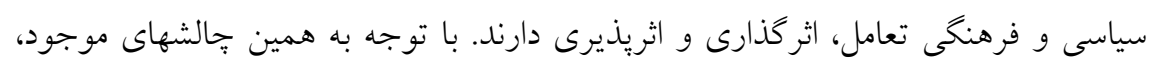

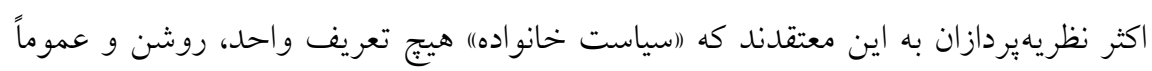

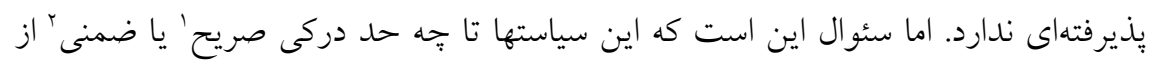

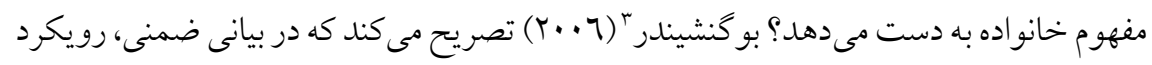

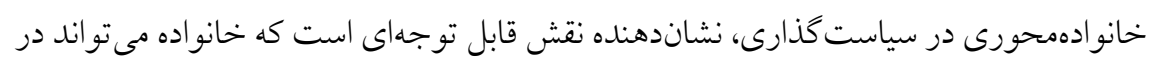

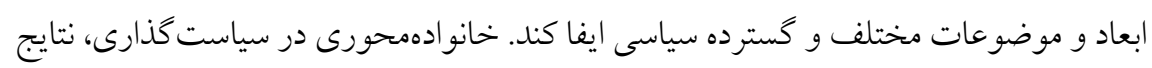

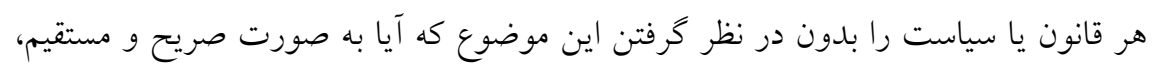

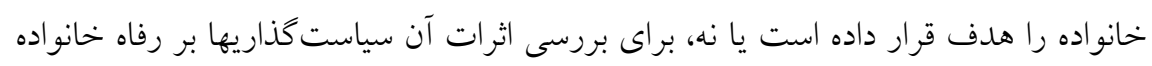

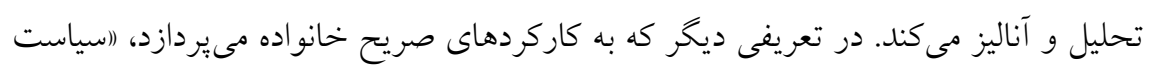

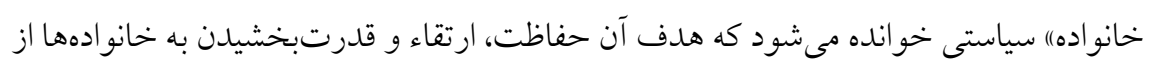

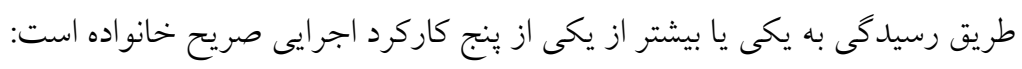

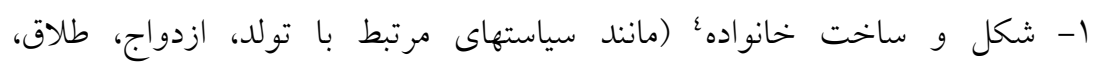

$$
\text { فرزندخواندگى، مراقبت جايكزين، ارث)؛ }
$$

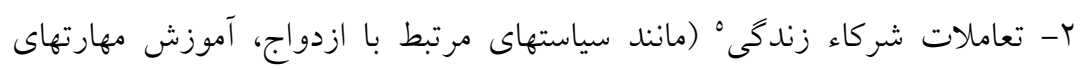

ارتباطى، انواع كمكهزينهها، انخيزشهاى مالياتى)

1. explicit

4. Family formation
2. implicit

5. partner relationships
3. bogenschneider 
r- حمايت اقتصادى (مانند سياستهاى مرتبط با درآمد، مواد غذايى، مسكن، آموزش

مشاغل و انواع تخفيفات مالياتى)

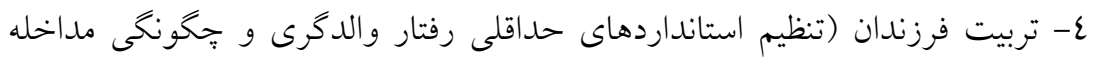

$$
\text { دولت در آن) و }
$$

0- مراقبت' (سياستهاى مداخله دولت بهعنوان مكمل يا جايخزين خانواده در مراقبت

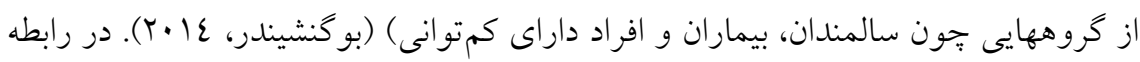

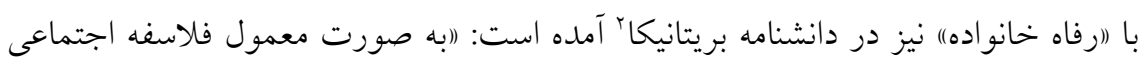

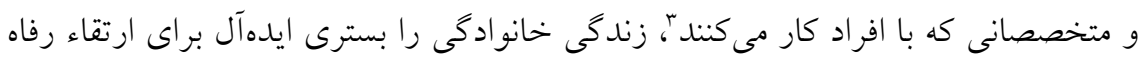

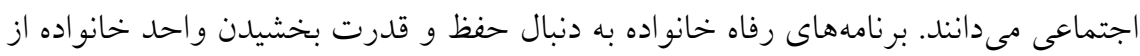

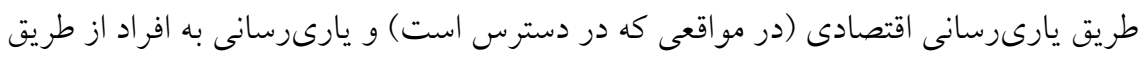
خدمات مختلف و متنوع است) (يينكرع، عالـ (Y).

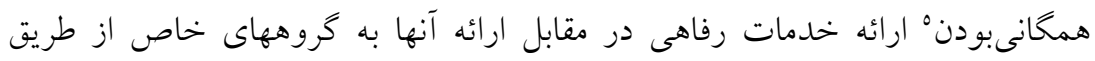

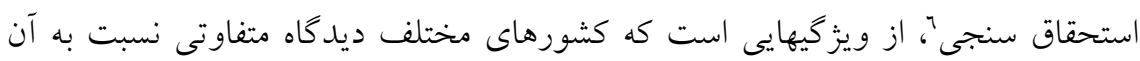

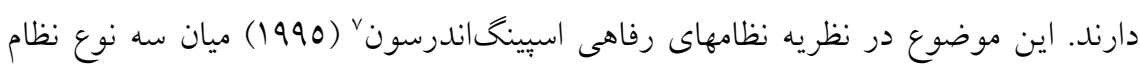

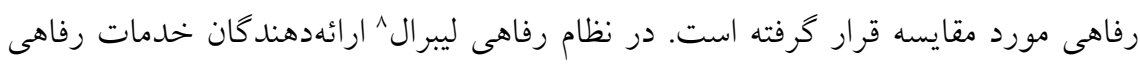

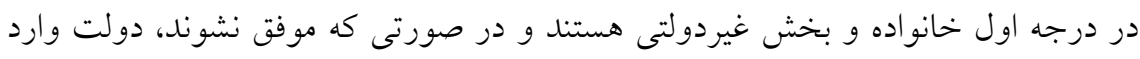

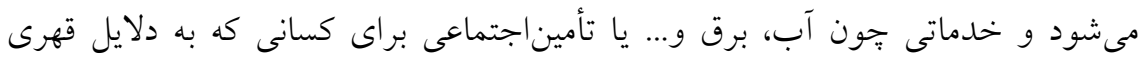

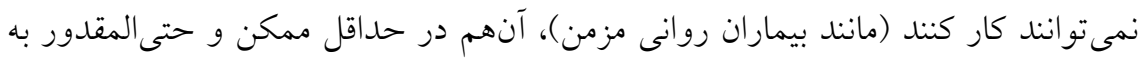

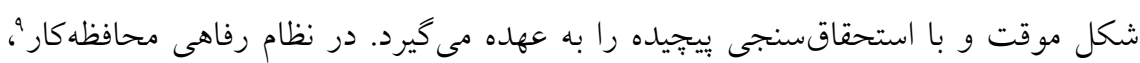

1. caregiving

4. Pinker

7. Gosta Esping-Anderson
2. britannica

5. universalism

8. liberal welfare states
3. case worker 6.means- testing

9. conservative 
توجه كمترى به استحقاق سنجى مىشود و دولت وظايفى براى تامين حداقل نيازها براى

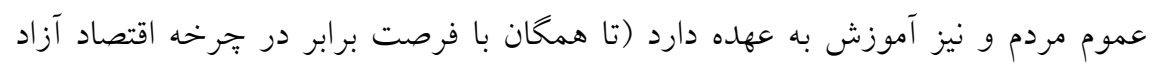

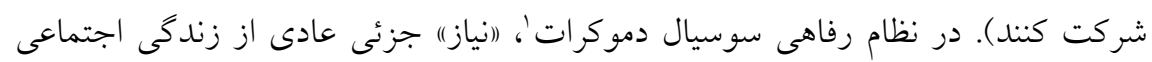

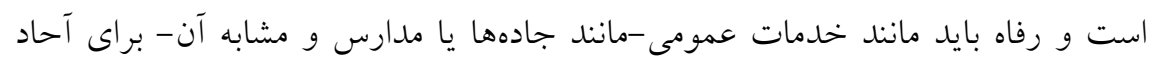

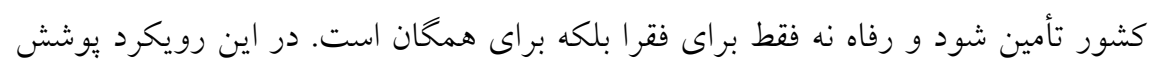

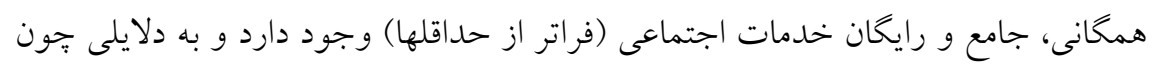

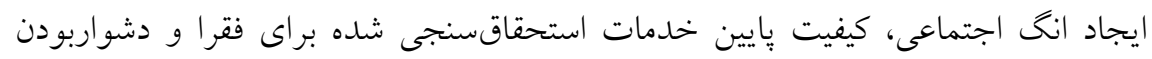

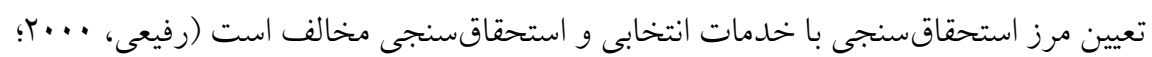

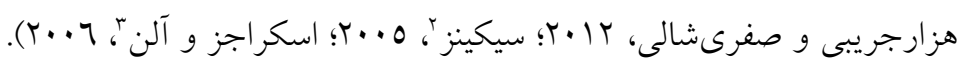

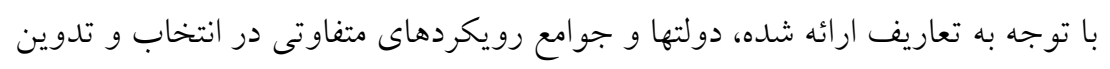

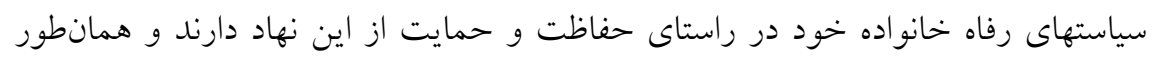

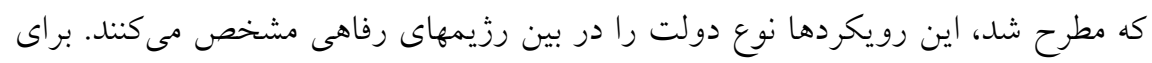

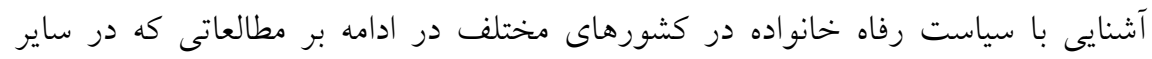

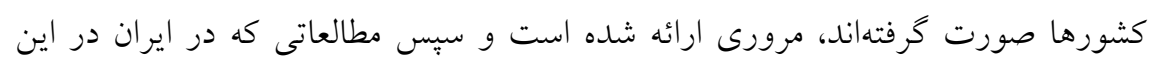
حوزه انجام شدهاند نيز به صورت مختصر شرح درده داده شدهاند.

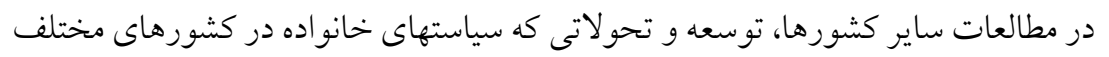

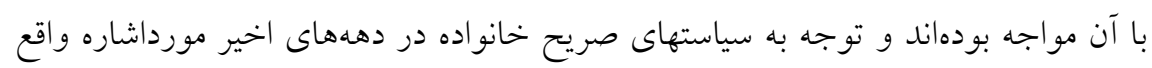

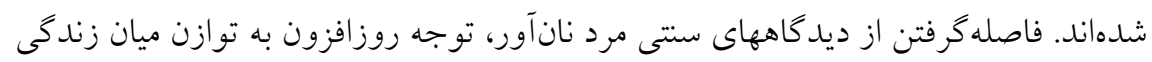

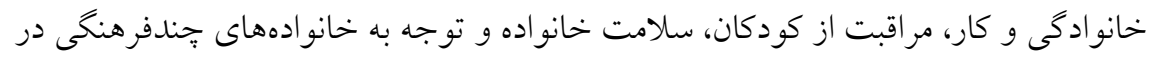

1. social democratic welfare states

2. Seekings

3. Scruggs and Allen 


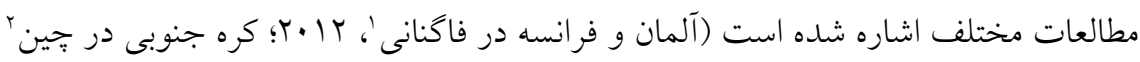

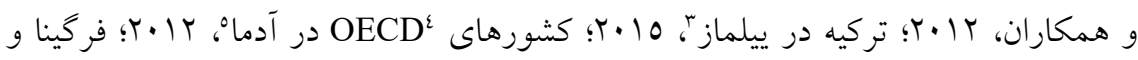

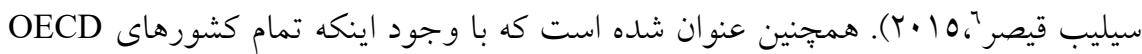
در سياستهاى عمومى خود از خانواده حمايت مى كنند، اما اين كشورها اهداف كوناكون و وابستهاى در اين راستا دارند. اهدافى جون كمك به خانواده براى ساز گارى ميان كار و مسئوليتهاى خانو اده؛ ارتقاى شرايطى كه به افراد بالغ كمك مى كند تا هر جند تعداد فرزند كه مى خواهند داشته باشند؛ ارتقاى بازار كار زنان و برابرى جنسيتى در راستاى رشد اقتصادى؛ مبارزه با فقر كودى و خانو اده و درنهايت ارتقاى رشد و آسايش كودى در مراحل اوليه زندگى كودى را مىتوان مورداشاره قرار داد (فر گينا و سيليب قيصر، 10 1)). از طرف ديخر در كشورهايى جون كلمبيا و اكوادور، خانوادههاى فقير، هدف اصلى سياستهاى خانواده در دو كشور هستند و بيشتر سياستها، به صورت ضمنى و نه صريح و مشخص براى اين گروه

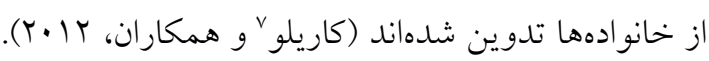
همجنين در منابع مختلف به جالشهاو مو انعى كه بر سر راه تدوين و اجراى سياستهاى خانو اده وجود دارد، اشاره شده است. براى نمونه مىتوان به تغييرات دموگر افيك خانو اده؛ تعريف محدود از خانواده ايدهآل؛ هنجارها و سنتهاى اجتماعى؛ عدم هماهنگىى ميان نهادهاى سياستخذارى و اجر ايى؛ عدم ثبات اقتصادى و سياسى؛ لزوم توجه به جامعيت و تناسب ابزارهاى سنجش سياست خانواده و توجه به حمايت از خانواده در مراحل اوليه زندكى كودى اشاره كرد (كشورهاى OECD

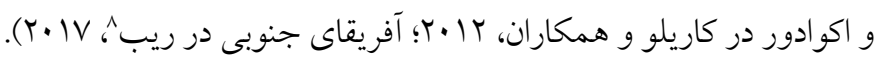

1. Fagnani 2. Chin 3. Yilmaz

4. The Organisation for Economic Co-operation and Development

5. Adema 6. Ferragina and Seeleib-Kaiser 7. Carrillo

8. Rabe 
مرورى بر مطالعات خارج از كشور نشان مىدهد كه در كشورهايى كه در وضعيت

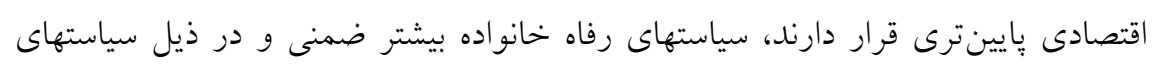

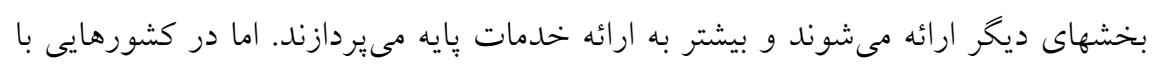

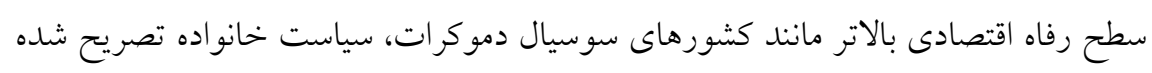

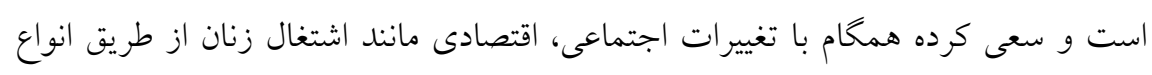

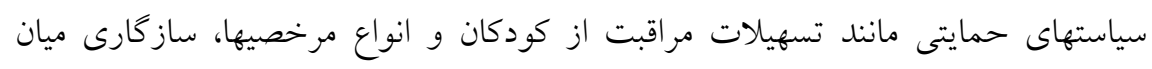
زندكى شغلى و خانوادكى را تسهيل كند.

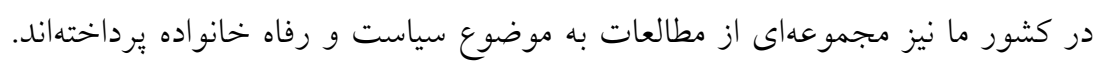

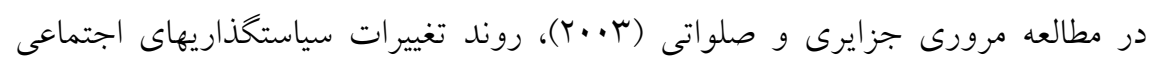

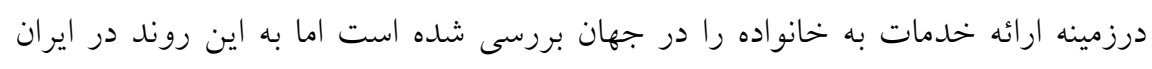

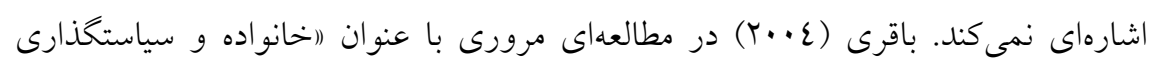

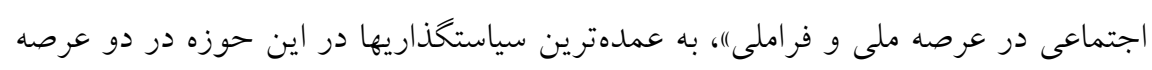

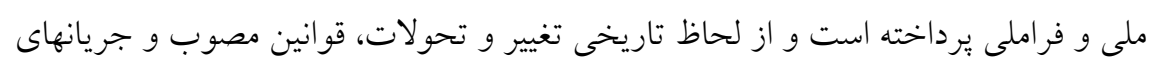

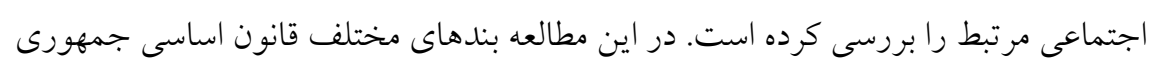

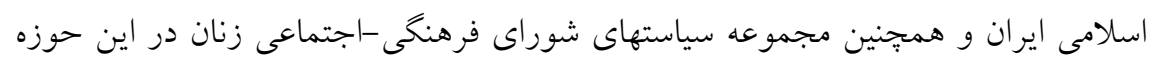

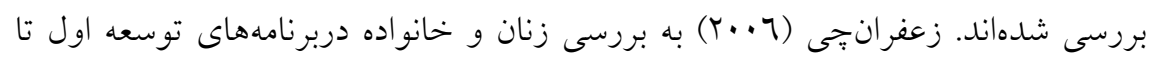

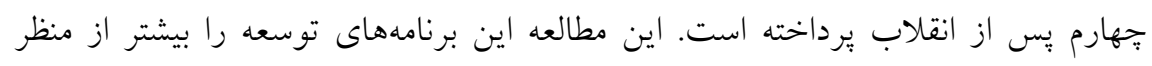

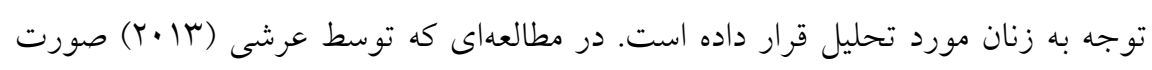

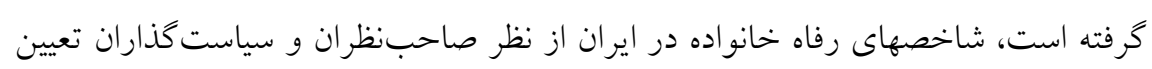

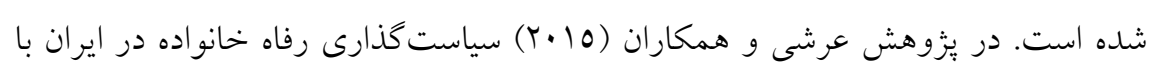

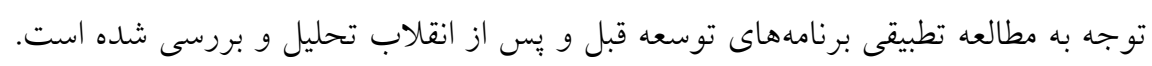

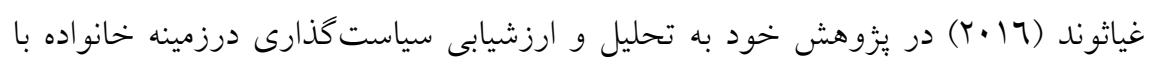


Social Welfare Quarterly, Vol 18, Fall 2018, No 70

تكيه بر طرح شكوفهاى عشق يرداخته است. اين طرح جهت توسعه و تقويت ازدواج يايدار جوانان شهر تهران با مشاركت نهادهاى مردمنهاد از سال Tیז| در حال اجرا است. با مرورى كه بر مطالعاتى كه در ايران در رابطه با سياست و رفاه خانواده صورت گرفتهاند، مىتوان عنوان كرد كه اين مطالعات كمتر به تحليل و تبيين عميق اين موضوع در كشور يرداختهاند، همجنين تعدادى از مطالعات ابعاد محدودى از سياست خانواده را مدنظر قرار دادهاند و يا در متن مطالعه بيشتر بر محوريت زنان بهجاى كل خانواده متمركز بودهاند. با توجه به يافتهاى اين مطالعات مىتوان عنوان كرد كه سياست خانو اده در ايران بيشتر ضمنى و غيرصريح است و سياستهاى مرتبط با اشتغال، اقتصاد، فرهنگ و... به صورت غيرمستقيم بر خانو اده اثر گذار هستند و قوانين و سياستهاى محدودى به صورت صريح و عينى خانو اده را محور قرار دادهاند.

همجنين اين موضوع قابل توجه است كه كشورهاى در حال توسعه جهون ايران، به دليل كذار از جامعه سنتى به جامعه مدرن، دستخوش تغييرات و تحولات مداومى هستند. اين

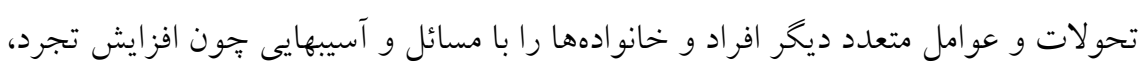
بالارفتن ميانخين سن ازدواج، افزايش شيوع طلاق، كاهش ميانخين عمر ازدواجها، افزايش زنان سريرست خانوار، روابط خارج از ازدواج، افزايش اشكال ديخر از زندكى مشترى جون همباشى، خشونت در فضاى مجازى و... مواجه ساخته است. كه مسلما سياستها و برنامهريزيهاى صورت كرفته در سطوح كلان و ميانى در كاهش و يا تقويت اين آسيبها اثر گذارند. اما در كشور ما سياست و رفاه خانواده هيج تعريف واحد، روشن و عموما يذ يذفتهشدهاى ندارند و عدم شناخت صحيح از شاخصهاى رفاه خانواده در ايران باعث مىشود كه در سياست گذاريهاى اجتماعى و اقتصادى الخويى براى نيل به اهداف وجود نداشته باشد. بنابراين لازم است كه در رابطه با سياستهاى رفاه خانو اده يزوهشها و بررسيهاى 
كسترده و عميقى انجام شود تا زيرساختهايى براى رسيدن به تعريفى جامع و واحد براى تبيين شاخصها فراهم شود. با توجه به موارد ذكرشده در رابطه با اهميت و ضرورت توجه به سياست و رفاه خانو اده در كشورها و همجينين عواملى جون اهميت نهاد خانواده، يراكندگى و كمبود اطلاعات و يُزوهشها در اين حوزه؛ يِيجيدگى مفهوم رفاه؛ دشوارى جداكردن رفاه اجتماعى از ديخر ابعاد اجتماعى، اقتصادى و سياسى و با توجه به نياز سياست گذاران به اطلاع از جايگاه ايران در خصوص رفاه خانواده، ضرورت برداختن به برنامهها و نخرش موجود در كشور به خانو اده

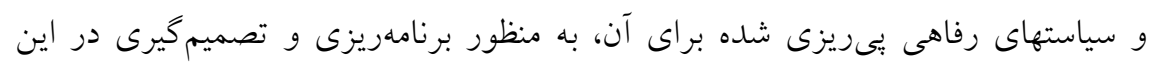
حوزه مبرهن است. همجنين همانطور كه عنوان شد، يكى از ويز گيهاى مهم رويكردهاى رفاهى در كشورهاى مختلف درجه همخانىبودن خدمات رفاهى است كه لازم است در كشور ما نيز مشخص شود، جِه سياستها و بهتبع آن خدماتى براى عموم خانو ادهها تدوين و

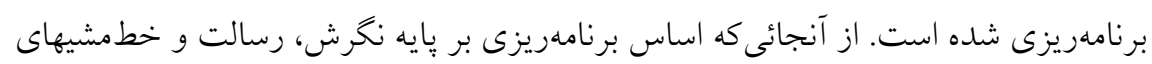

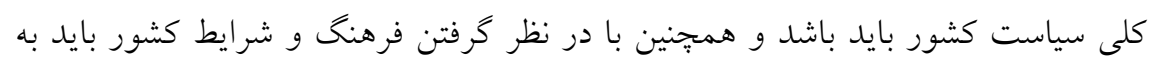

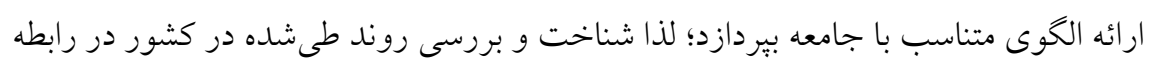

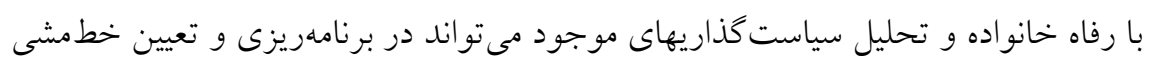
بيش رو نقش قابل توجهى داشته باشد. لذا اين بيزوهش سعى بر آن دارد تا سياستهاى خانو اده در ايران، يُ از انقلاب جمهورى اسلامى ايران را با توجه به اسناد و قوانين موجود بررسى و تحليل كند. عيان است كه براى رسيدن به اين منظور، اسناد بالادستى كشور، تعيين كنندهترين و دسته اولترين منابع براى شناخت موضوع هستند كه مىتوانند انعكاسدهنده نوع رويكرد

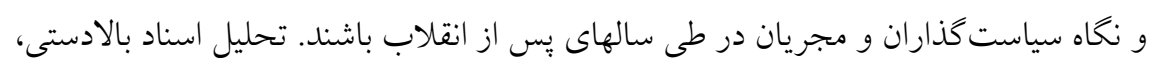
قوانين و برنامهاى توسعه و سياست گذاريهاى خانواده در ايران در جهار دهه كذشته، كمبودها و نقاط قوت را مشخص خواهد كرد. لذا اين موارد زمينهاى براى برنامهريزى در 
Social Welfare Quarterly, Vol 18, Fall 2018, No 70

اين خصوص را بيشروى سياست گذاران و مجريان قرار مىدهد. از طرف ديخر رسيدن به يك تعريف واحد از خانواده بهويزه با تحولات جامعه امروز يِيجيده و دشوار است. اما درنظر گرفتن تعريفى كه سياست گذاران در برنامهها و اقدامات خود آن را محور و مبناى كار خود قرار دهند، ضرورت دارد. تا بتوان آن را مبناى اين مطالعه قرار داد. لذا در اين مطالعه منظور از خانواده واحدى است كه شكل قانونى و ثبتى دارد و شامل يدر، مادر، زن، شوهر، فرزندان و فرزندخوانده مىشود. در اين تحقيق خانوادههاى مجرد، اشكال ديخر خانواده مانند خانوادهاى همجنس گرا و خانوادههاى ازهم گسيخته مدنظر نيستند. همجينين در اين مطالعه، تعريف بو گنشيندر (ع| (Y) از سياست خانواده، با توجه به جامعيت و عملياتى تر بودن تعريف، مبناى مطالعه در مراحل مختلف قرار داده شده است. درواقع سياستهاى رفاه خانواده در اين تحقيق شامل آن دسته سياستهايى مىشود كه براى گسترش رفاه خانواده بيشتر توسط دولت، طرحريزى مىشوند و اقدامات مبتنى بر آنها

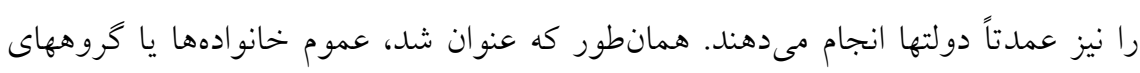
مختلف اجتماعى مى توانند مخاطب سياست رفاه خانواده باشند كه در اين مقاله به صورت مشخص سياستهايى كه عموم خانو ادهها را مخاطب قرار دادهاند، موردبررسى قرار گرفته شده است. (لازم به ذكر است كه اين مقاله، بخشى از طرح يزوهشى "(مرور و نقد سياستهاى رفاه خانواده در ايران) است كه زير نظر مركز تحقيقات رفاه اجتماعى دانشخاه علوم بهزيستى و توانبخشى در سال عوس|-90ب| صورت گرفته است) 
يارادايم اين مطالعه كيفى است و برنامهها و سياستهاى اجتماعى حوزه خانواده، تحليل محتواى كيفى شدهاند. تحليل محتواى كيفى به فراسويى از كلمات يا محتواى عينى متون

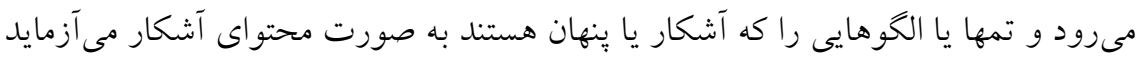

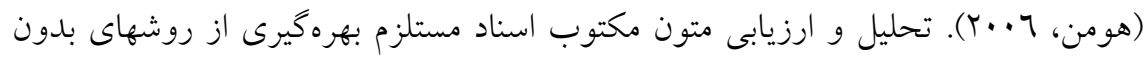
و اكنش مانند تحليل محتوا با هدف يافتن محتواى درون متنى است (كاردوانى و همكاران،

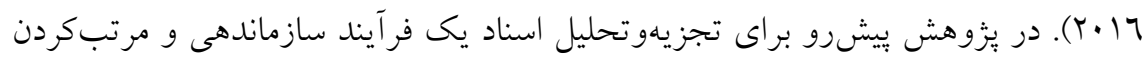

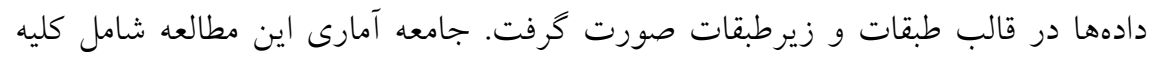

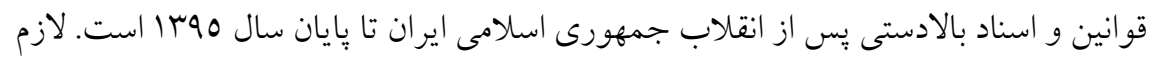

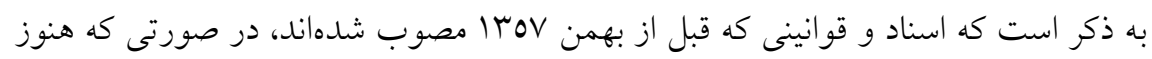

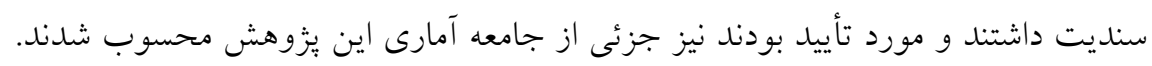

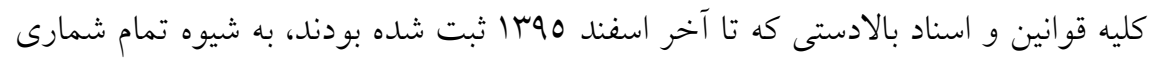

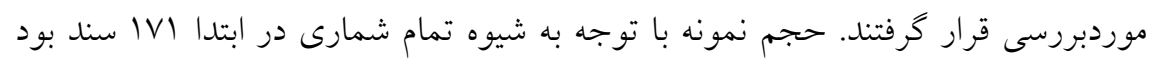

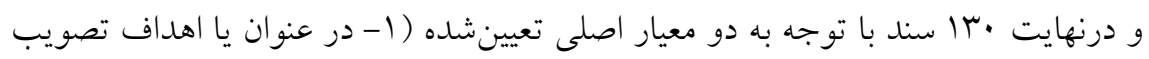

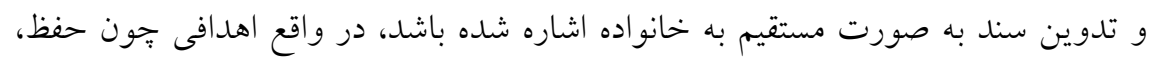

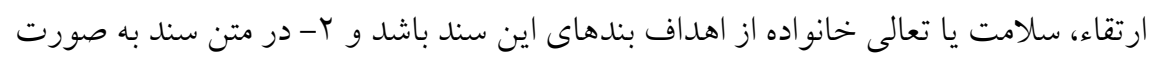

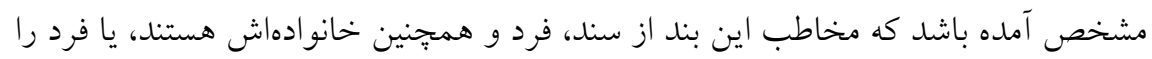

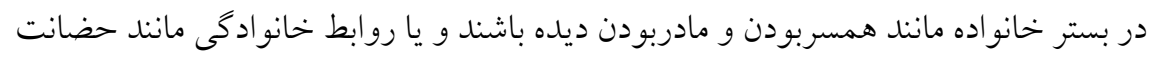

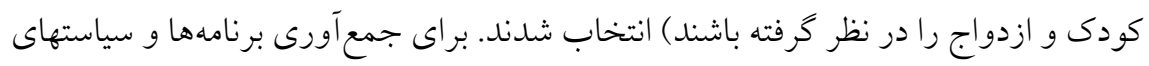

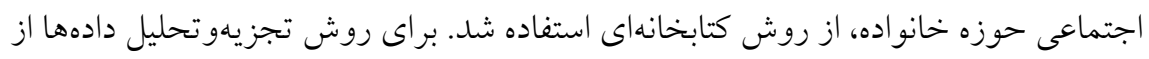

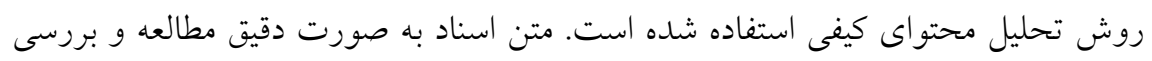


شدند تا مفاهيم و تمهاى اصلى استخراج شوند. اين كار در يك فرايند رفت و برگشنى و به

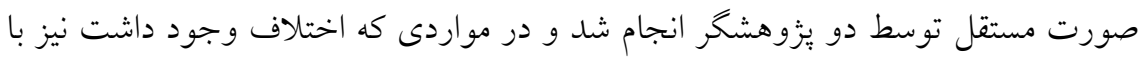
كمى نفر سوم تصميم گيرى صورت كرفت.

فرايند انجام اين مطالعه بدين كونه بوده است كه براى دسترسى بـ به كليه قوانين و اسناد

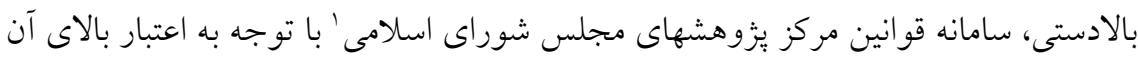

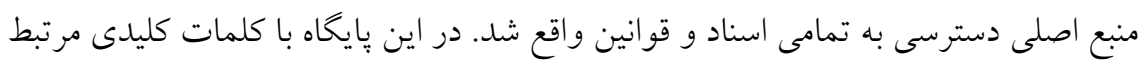

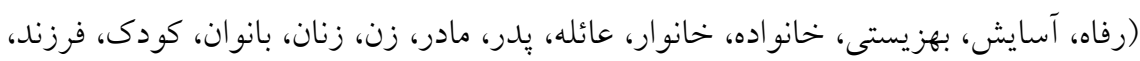

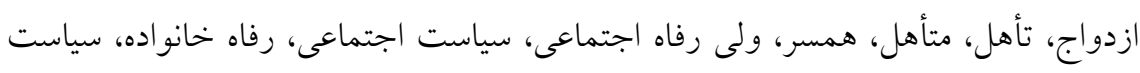

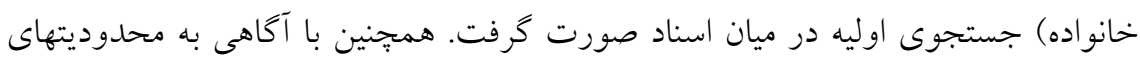
موجود در جستجو به زبان فارسى و همجنين قدرت يايين موتور جستجوى اين سامانه؛

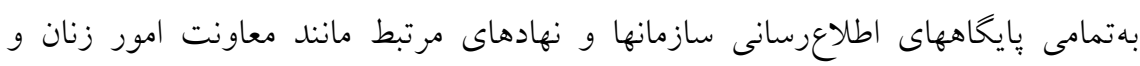

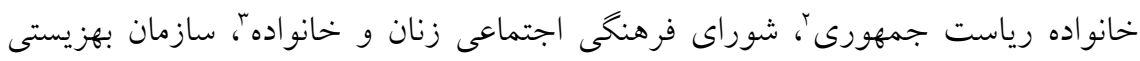

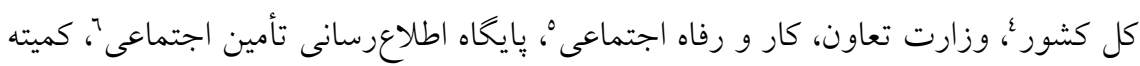

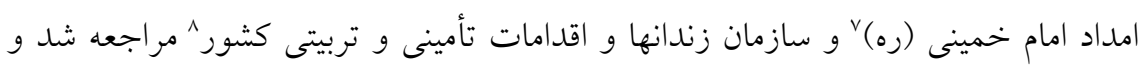

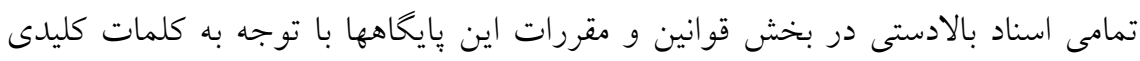
موردبررسى واقع شدند. در مرحله اوليه حدود

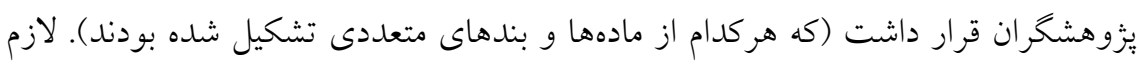
بود متن اين اسناد جهت استخراج اسناد مرتبط موردبررسى دقيق واقع شوند، لذا با توجه

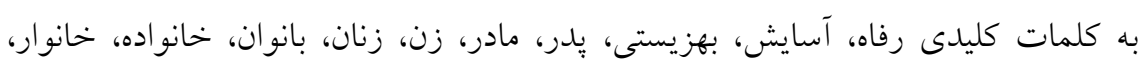

1. http://rc.majlis.ir/fa/law

3. http://zn.farhangoelm.ir/Home

5. https://www.mcls.gov.ir/

7. http://portal.emdad.ir/
2. http://nahad.govir.ir g http://women.gov.ir

4. http://www.behzisti.ir

6. http://www.tamin.ir/

8. http://prisons.ir/ 
عائله، كودى، فرزند، باردارى، زايمان، ازدواج، تأهل، متأهل، همسر، طلاق، حضانت، قيم،

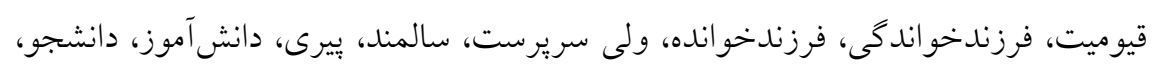

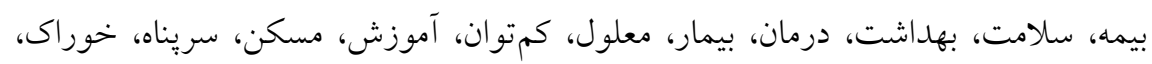

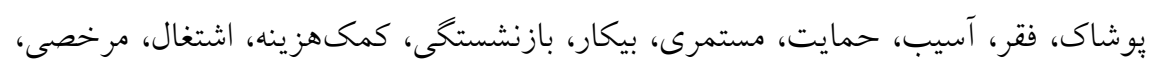

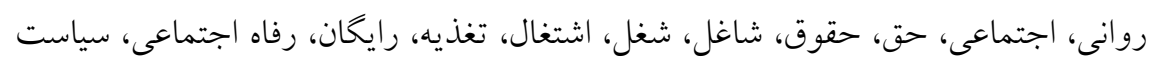

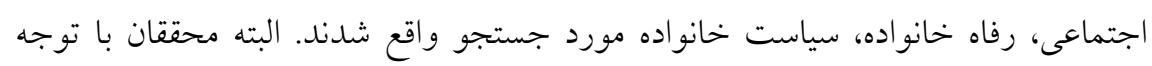
به محدوديتهاى جستجوى فارسى در متون تقريبا در تمامى اسناد به دست آمده، مجبور به ونه

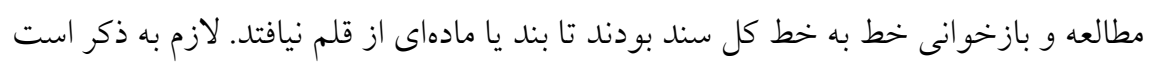

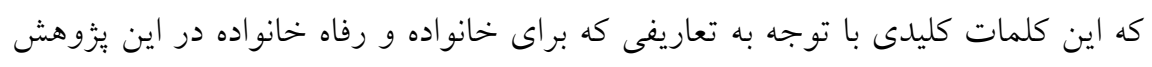

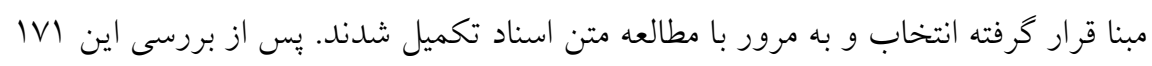

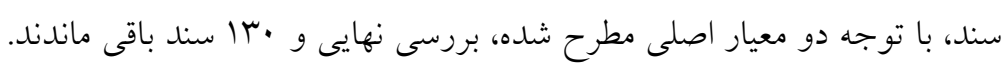

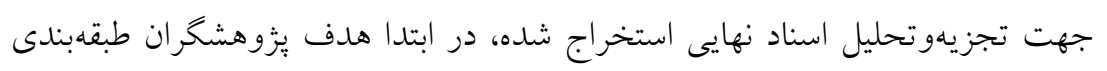

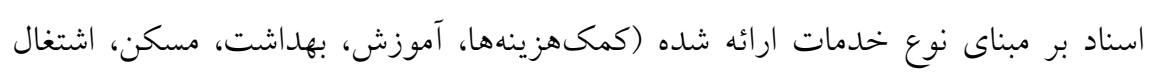

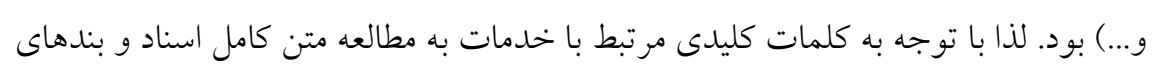

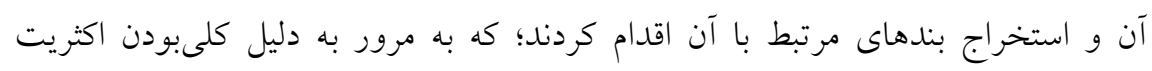

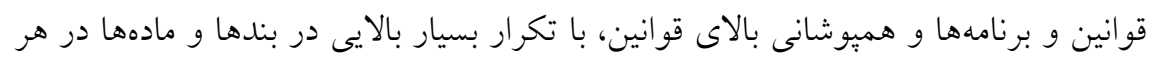

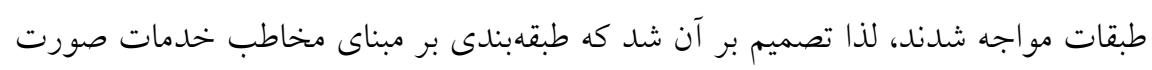

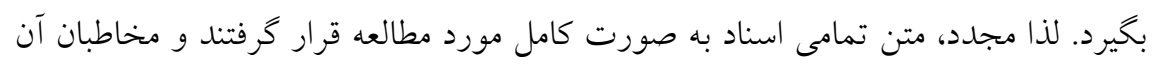

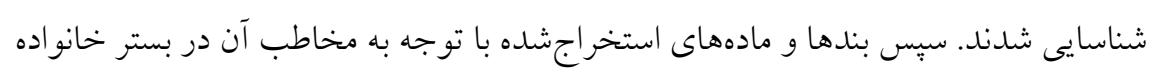

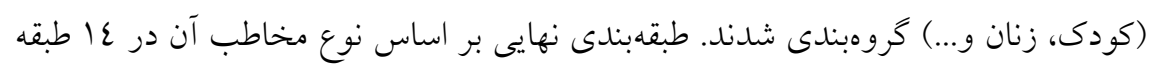

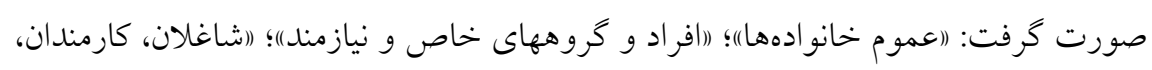

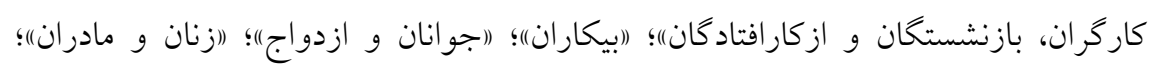


Social Welfare Quarterly, Vol 18, Fall 2018, No 70

((مردان و يدران)؛ ((كودكان)؛؛ ((سالمندان)؛؛ (روستائيان و عشاير)؛ (شهدا و ايثارگران)؛ ((طلاب و دانشجويان)؛ ((سربازان)) و (معلولان)). لازم به ذكر است كه در استخراج و طبقهبندى اسناد، براى بيشخيرى از تكرار و همبوشانى بالاى قوانين جارجوبى توسط خود محققان تعيين و در تمام طول كار رعايت شد؛ براى نمونه موارد مرتبط با (فرزندان)) در (اعموم خانو ادهها)) آمدهاند، مخر در مواردى كه از عنوان كودك استفاده شده و يا زير ل1 سال بودن مشخص شده باشد در (كودكان) آمده اند. همانطور كه عنوان شد در اين مقاله صرفا به سياستهاى مرتبط با عموم خانو ادهها برداخته مىشود.

\section{إفته ها}

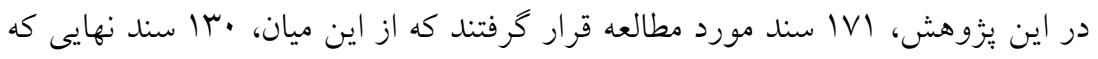
مرتبط با حوزه سياست اجتماعى خانواده بودند، استخراج شدند. مراجع تصويب اين اسناد شامل مجمع تشخيص مصلحت نظام، مجلس خبر كان، مجلس شوراى اسلامى، مجلس شوراى ملى، ديوان عالى كشور، نخستوزيرى، هيئتوزيران، قوه قضائيه، مصوبات شوراى عالى ادارى، شوراى عالى انقلاب فرهنخى، شوراى عالى كار، سازمان برنامهوبودجه و سازمان بهزيستى كل كشور هستند. همجنين همانطور كه عنوان شد در اين يزوهش عا گروه بهعنوان مخاطب سياستهاى خانواده استخراج شدند كه در اين مقاله، يافتهاى حاصل از مب سندى كه مرتبط با (اعموم خانو ادها)) هستند، گزارش (جدول شماره () و در ادامه مورد تحليل قرار گرفتند.

در اين اسناد، در هشت سند به مسائل مرتبط با سياستهاى تنظيم خانواده (افزايش يا

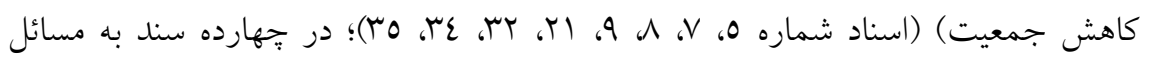

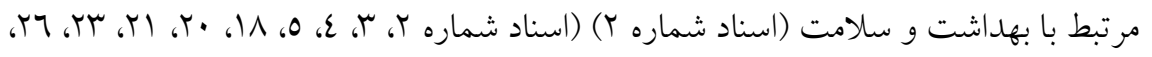

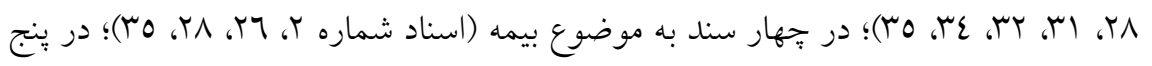


سند به نياز اساسى مسكن خانو اده و وظيفه دولت براى تأمين آن (اسناد شماره ب، با، $10 ،$

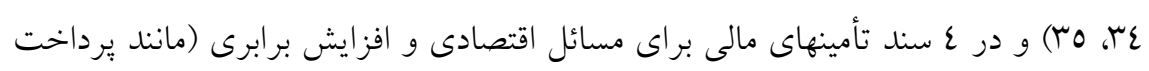

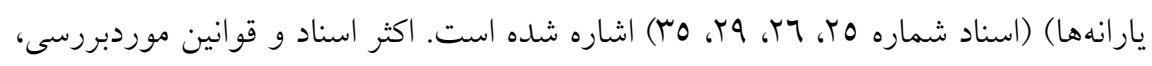

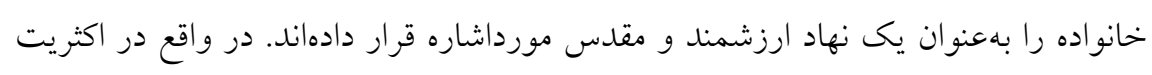

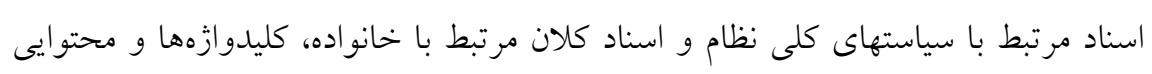

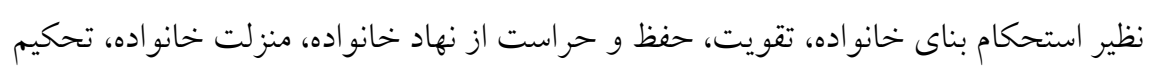

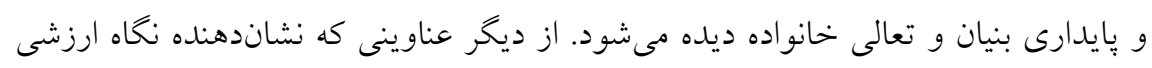

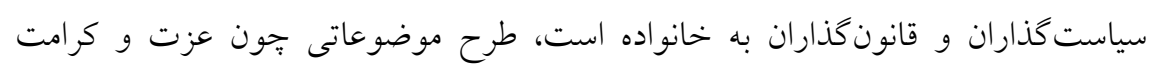

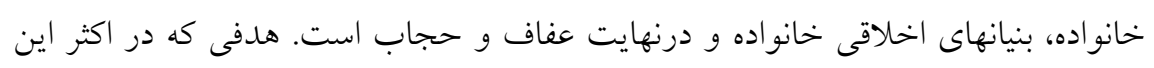

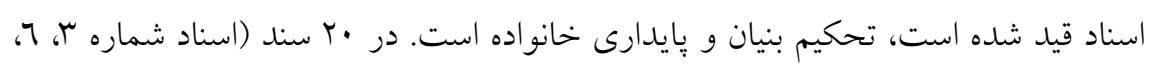
•)

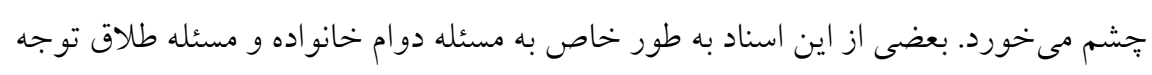

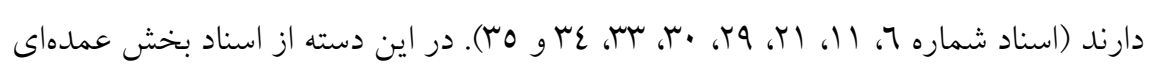

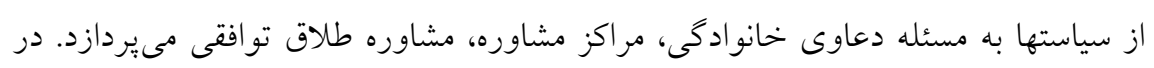

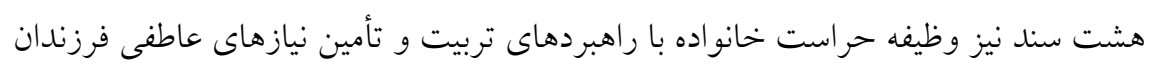

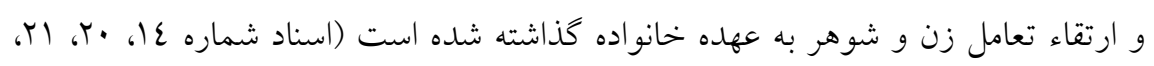

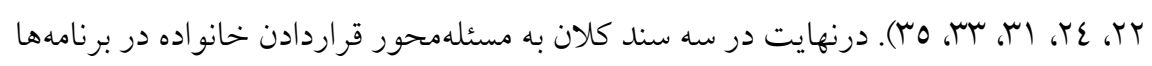

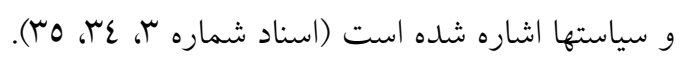


جدول (1) اسناد و قوانين مرتبط با سياست اجتماعى خانواده در عموم خانوادهها (به ترتيب تاريخ اوليه تصويب)

\begin{tabular}{|c|c|c|c|}
\hline بند/ماده مرتبط و موضوع آن & مرجع و تاريخ & ن ام قانون & $\hat{3}$ \\
\hline 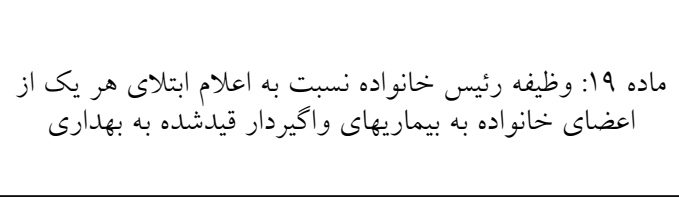 & | - مجلس شوراى & 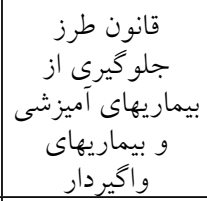 & 1 \\
\hline 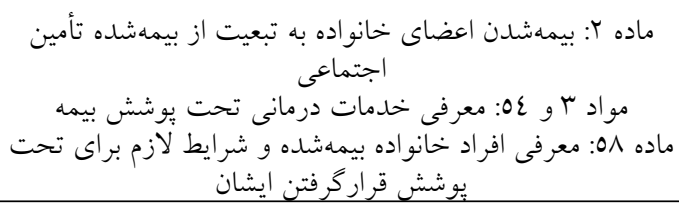 & 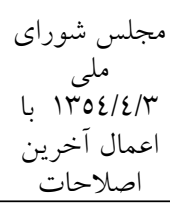 & قانون تامين & $r$ \\
\hline 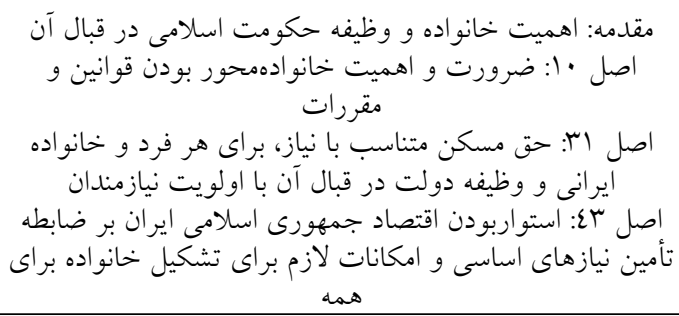 & 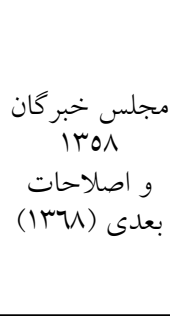 & جمانون اساسى اسلامى & $r$ \\
\hline 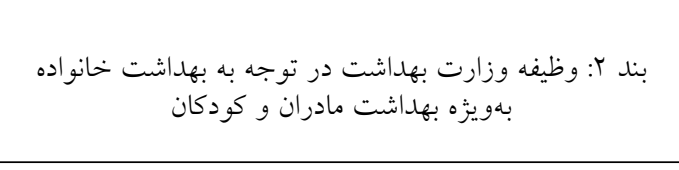 & مجلس شوراى & قو وقانون تشكيلات وزارت & $\varepsilon$ \\
\hline 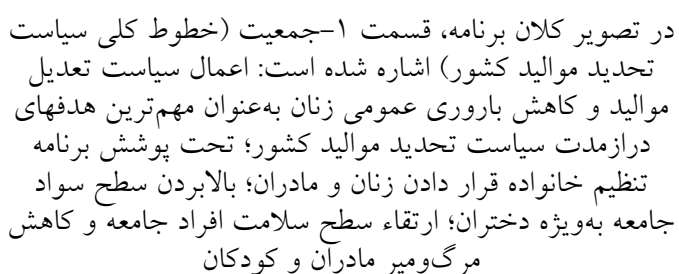 & مجلس شوراى اسلامى & برنامه اول توسعه & 0 \\
\hline
\end{tabular}


سياستهاى فراخير رفاه خانواده در /يران

Universal Family Welfare Policies in Iran

\begin{tabular}{|c|c|c|c|}
\hline و موضوع آن & مرجع و تاريخ & نام قانون & \\
\hline 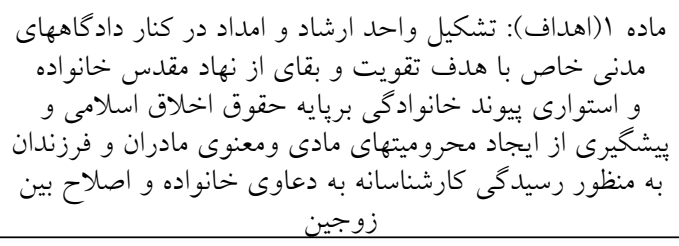 & شوابلاب فرهنكى عالى & كنار داد ماداهيل وامداد در & 7 \\
\hline 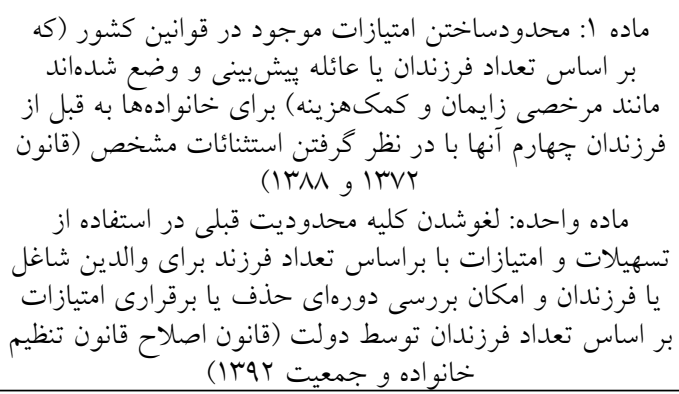 & اسلامي شلس شوراى & خانون تنظيم & V \\
\hline ـ. 1) در دانشخاهـ & 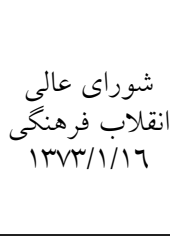 & 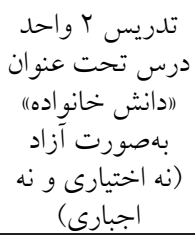 & $\wedge$ \\
\hline 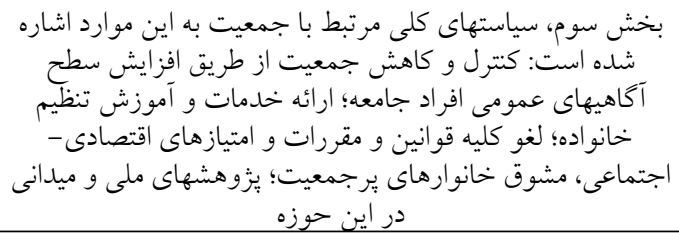 & مجلس شوراى اسلامى & برنامه دوم توسعه & 9 \\
\hline 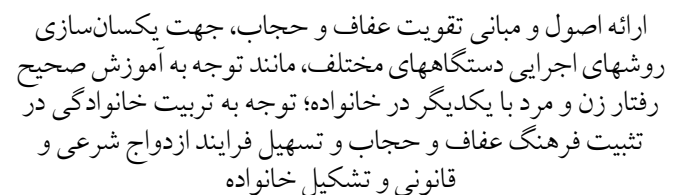 & 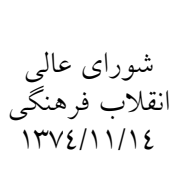 & 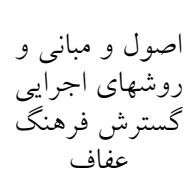 & 1. \\
\hline
\end{tabular}




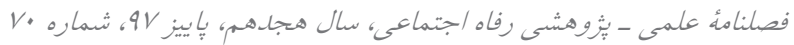

Social Welfare Quarterly, Vol 18, Fall 2018, No 70

\begin{tabular}{|c|c|c|c|}
\hline 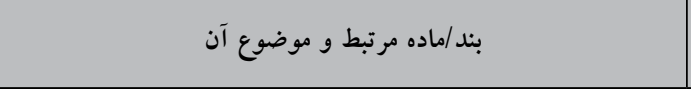 & مرجع و تاريخ & ن ام قانون & \\
\hline 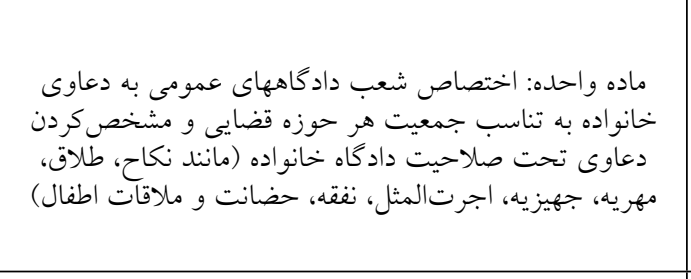 & مجلس شوراى اسلامى & 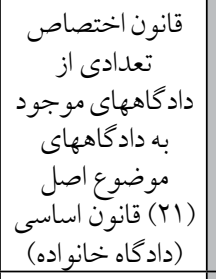 & 11 \\
\hline ـه و جايحاه زن در آن & | مجمع تشختص نظم & | برنامه سوم توسعاى كلى | & $1 T$ \\
\hline 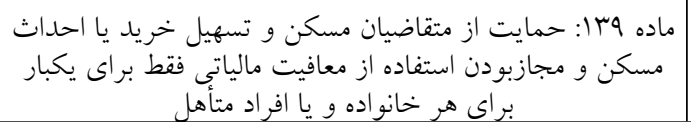 & مجلس شوراى اسلامى & |برنامه سوم توسعه & ir \\
\hline 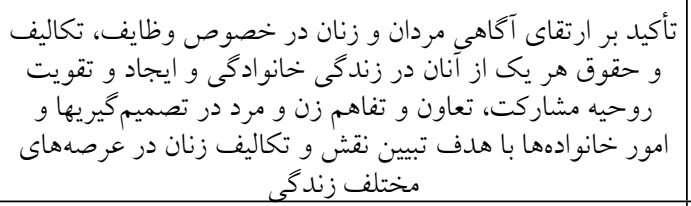 & |نقاب فرواى عالى هنى & فرهنى - نرياستهاى & $1 \varepsilon$ \\
\hline |بند م: توجه به ارز & مصلحع تشخت نظام & 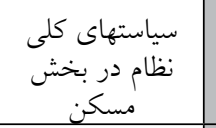 & 10 \\
\hline بند ه (امور فرهنىى): توجه به جايخاه زنان و ارتقاى نقش آن & مجمع تشخيص نظمام & سياستهاى كلى نظم دوره & 17 \\
\hline بند عا(امور اجتماعى، سياسى دفاعى و آنيتى): تقويت نهاد & 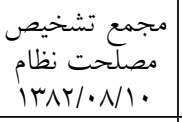 & 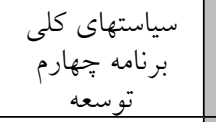 & IV \\
\hline لزوم برخوردارى كشور از نهاد مستحكم خانو اده & 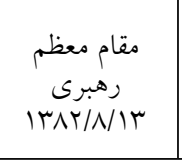 & 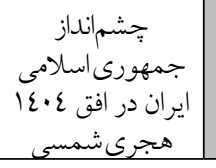 & \\
\hline
\end{tabular}


سياستهاى فراكير رفاه خانو/ده در /يران

Universal Family Welfare Policies in Iran

\begin{tabular}{|c|c|c|c|}
\hline موع آن & مرجع و تاريخ & نام قانون & \\
\hline 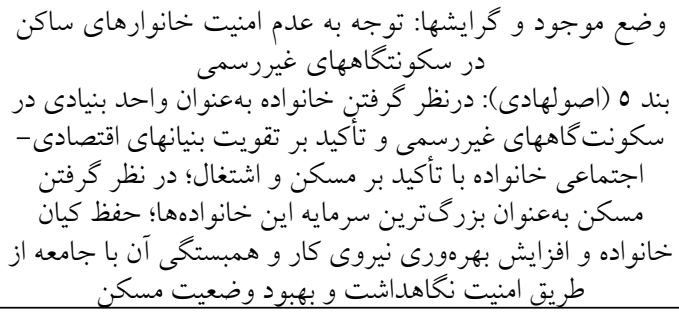 & 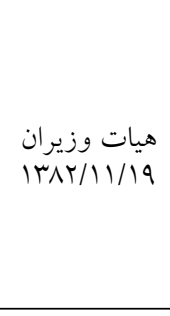 & 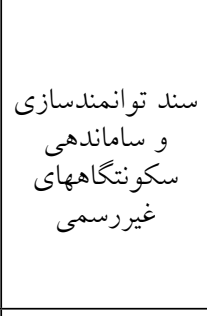 & 19 \\
\hline 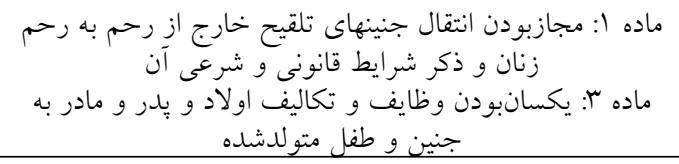 & مجلس شوراى & 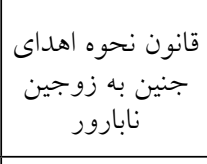 & $r$. \\
\hline 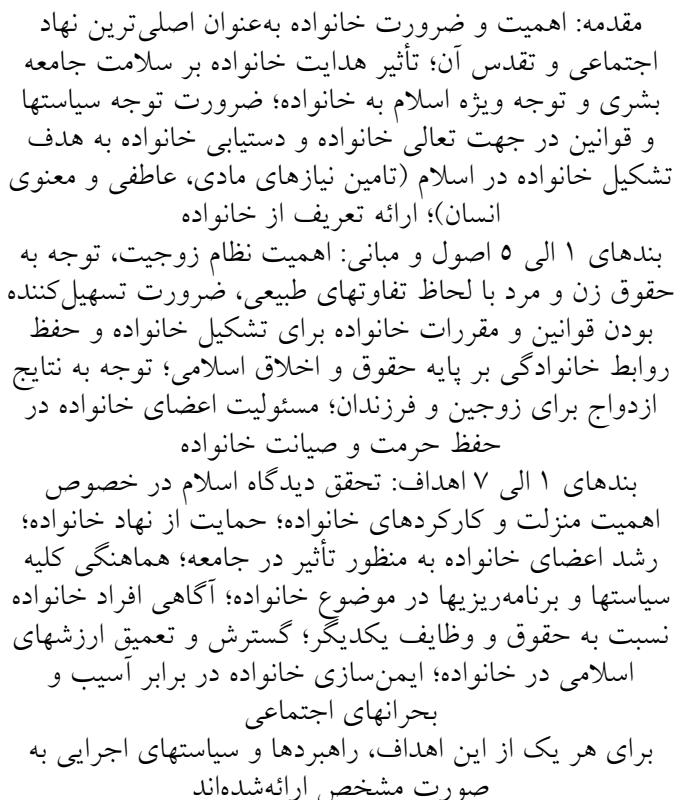 & شواب فرهاى عالى & 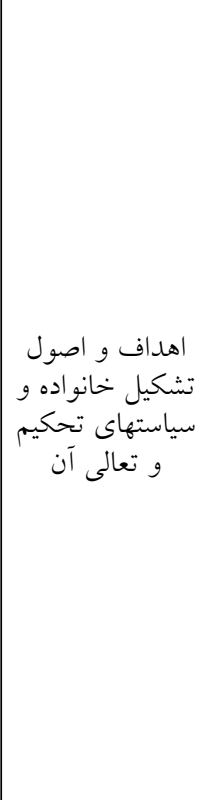 & $r \mid$ \\
\hline
\end{tabular}




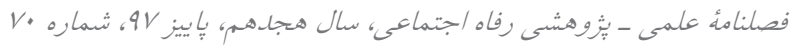

Social Welfare Quarterly, Vol 18, Fall 2018, No 70

\begin{tabular}{|c|c|c|c|}
\hline رتبط و موضوع آن & مرجع و تاريخ & 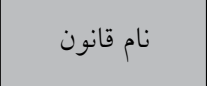 & \\
\hline 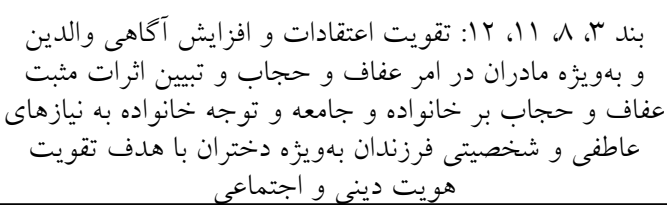 & 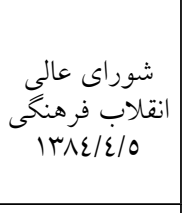 & كسترش فرهنَ & rr \\
\hline 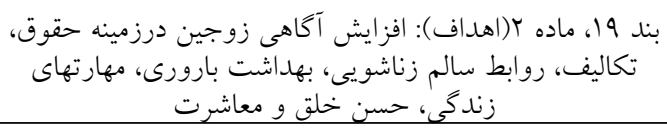 & 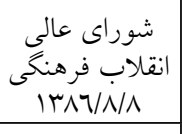 & 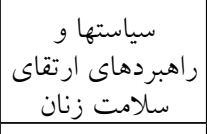 & rr \\
\hline ت نهاد خانو اده و جايكاه زن در آن & مصلحع تشخت نظام & سباستهاى كلى بنى بنجم & $r \varepsilon$ \\
\hline 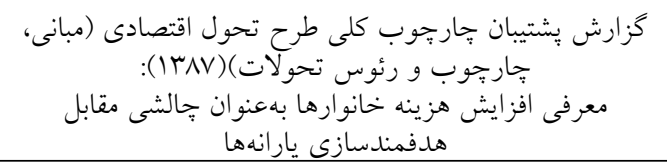 & مجلس شوراى & طرح تحول & ro \\
\hline 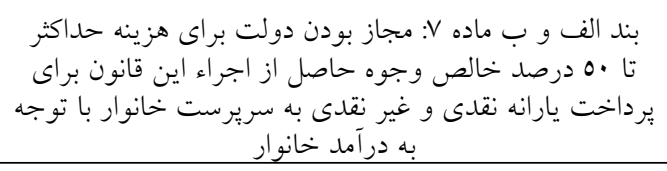 & 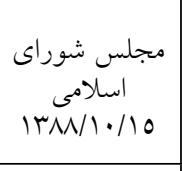 & قردن يارن هدفمها & rq \\
\hline 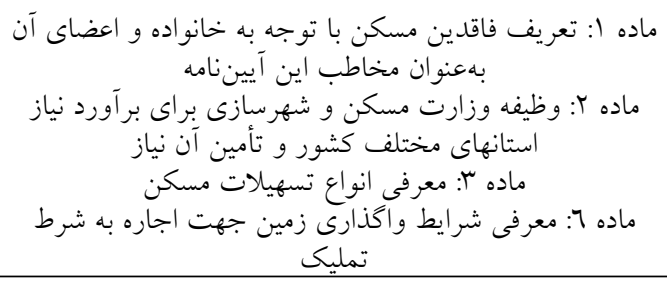 & هيئتوزيران & 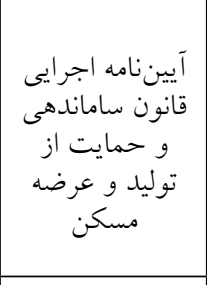 & rV \\
\hline 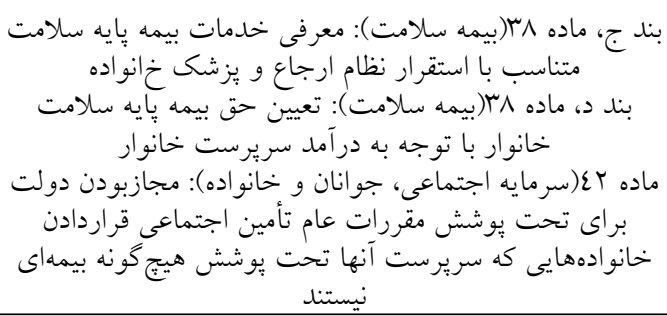 & مجلس شوراى 10 |سلامى| & برنامه ينجم & rA \\
\hline
\end{tabular}


سياستهاى فراخير رفاه خانواده در ايران

Universal Family Welfare Policies in Iran

\begin{tabular}{|c|c|c|c|}
\hline لـ و موضوع آن & مرجع و تاريخ & نام قانون & \\
\hline 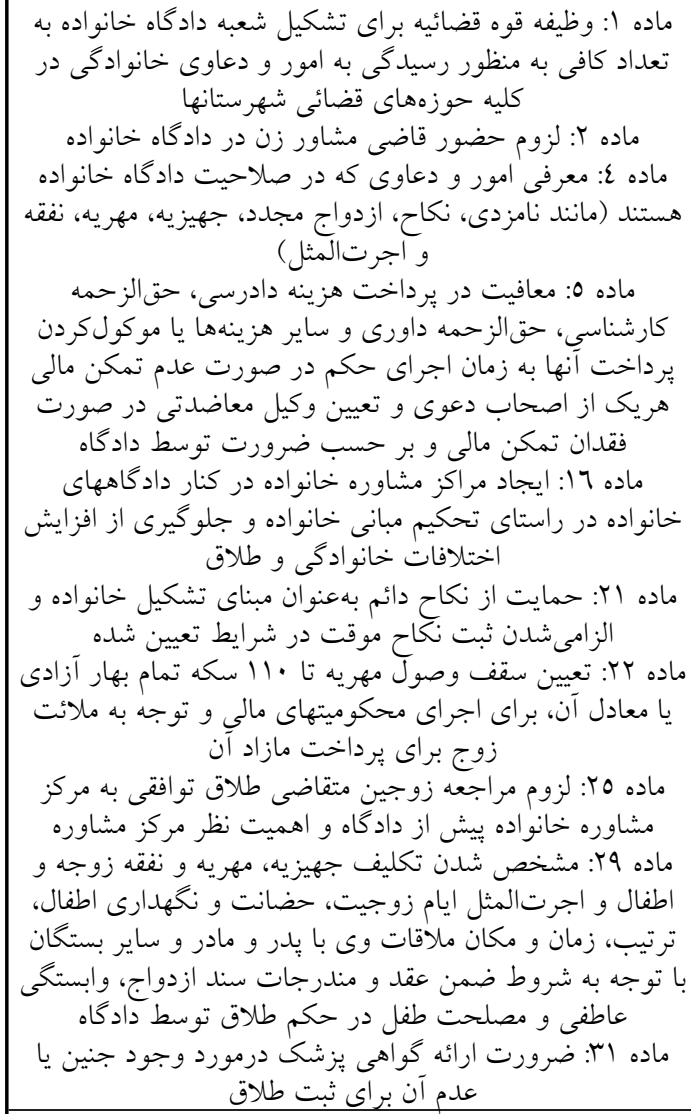 & 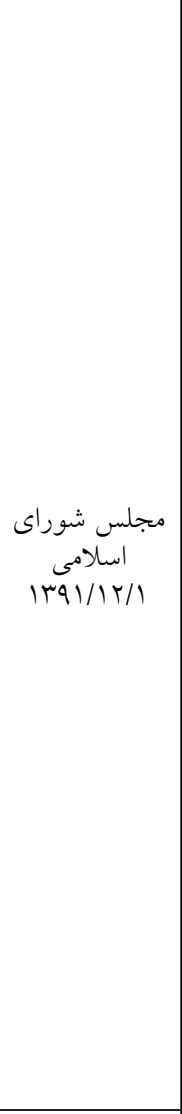 & قانون حمايت & rq \\
\hline 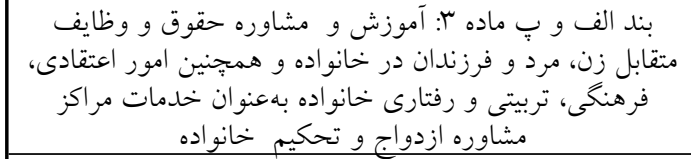 & 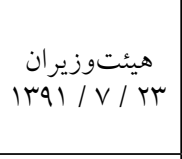 & 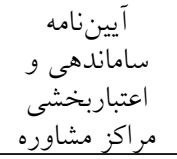 & r. \\
\hline 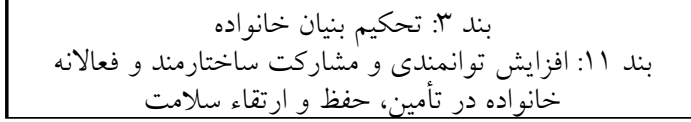 & مصلحع تشخت نظام & سياستهاى كلى سلى & rI \\
\hline
\end{tabular}




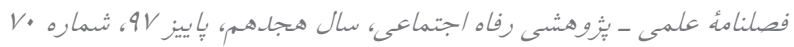

Social Welfare Quarterly, Vol 18, Fall 2018, No 70

\begin{tabular}{|c|c|c|c|}
\hline بند/ماده مرتبط & ترجع و تاريخ & 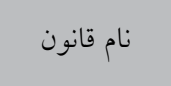 & \\
\hline 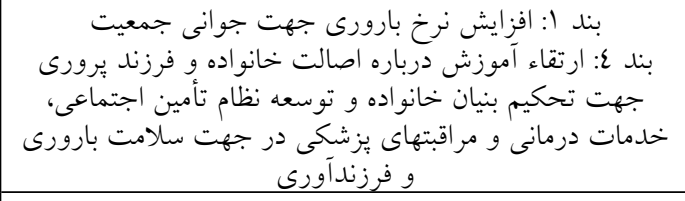 & مجمع تشختص & سياستهاى كلى & rY \\
\hline ماده 7§(امور اجتماعى): تقويت نها & مجمع تشخيص نظام & برناستهاى شلى شئى & $\pi$ \\
\hline 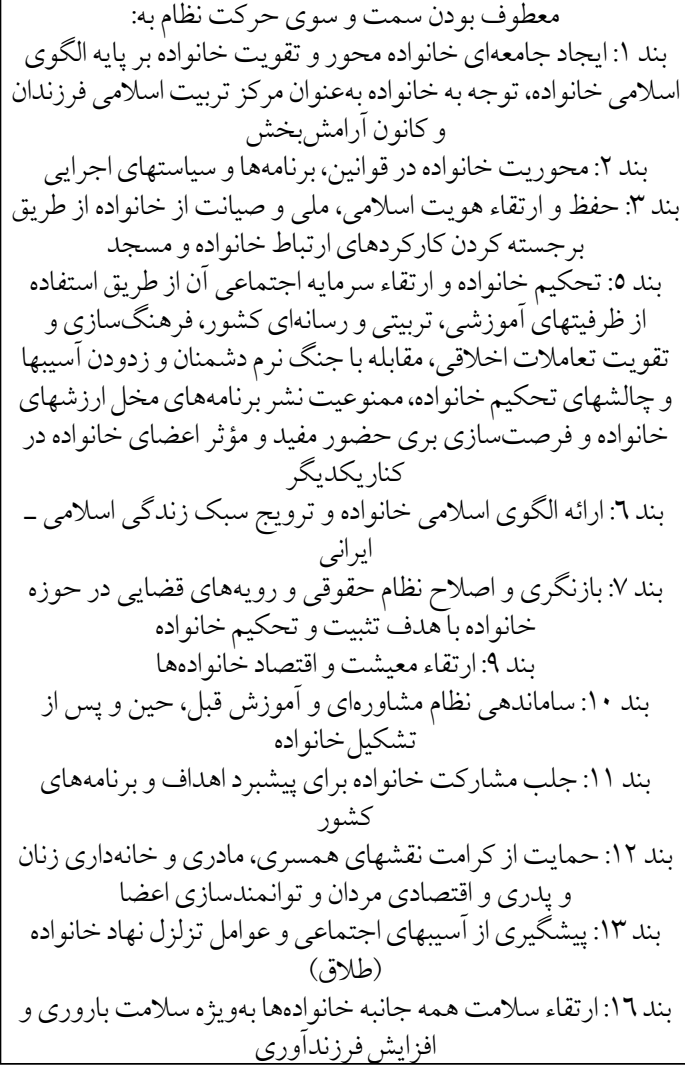 & مجصمع تشخيص نظام & سياستهاى كلى & $r \varepsilon$ \\
\hline
\end{tabular}


سياستهاى فراكير رفاه خانواده در ايران

Universal Family Welfare Policies in Iran

\begin{tabular}{|c|c|c|c|}
\hline و موضوع آن & مرجع و تاريخ & نام قانون & \\
\hline 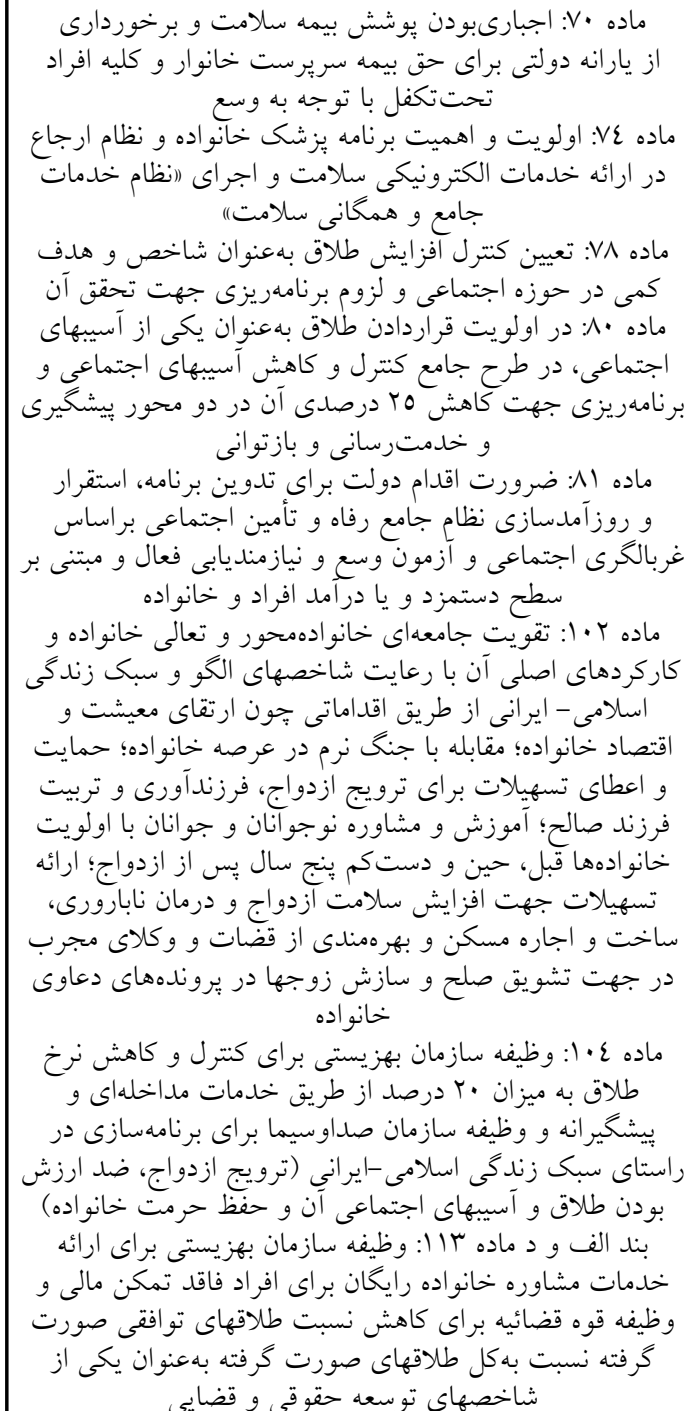 & عجلس شوراى اسلامى 1 / & برنامه شعه & ro \\
\hline
\end{tabular}


يافتههاى حاصل از مطالعه و تحليل سياستها و قوانين از جهات و ابعاد متفاوتى قابل توجه و ارائه هستند. يكى از اين ابعاد، سطوح يا مراتب خط مشى كذارى است. مجمع تشخيص مصلحت

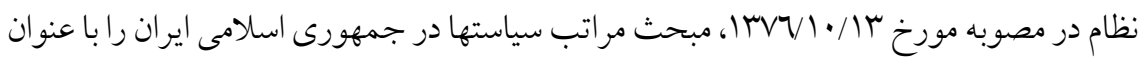
((سياست و مراتب آن) به تفصيل مطرح كرده است. در اين مصوبه آمده است: در يك نظام آرمانى و هدفدار، برنامهريزى به معنى عام را مىتوان دربر گيرنده مراتب زير دانست: ا- سياستهاى كلى: سياستهايى كه براى تحقق آرمانها و اهداف، يس از مجموعه آرمانها قرار مى گيرند و حاوى لئ اصولى هستند كه آرمانها را به مفاهيم اجرايى نزديك مى كنند و شامل سياستهاى (ابخشى و فرابخشى" هستند. Y- سياستهاى اجرايى: مجموعه تدبيرها و سياستهايى هستند كه براى تحقق سياستهاى كلى، توسط قواى مختلف كشور و دستخاههاى اجرايى، بر اساس مقررات قانونى، تدوين مىشوند. r-برنامهها: طر احى عملى و وجه اجر ایى سياستهاى اجر ايى هستند كه بر ایى دوره مشخصى تدوين و تنظيم مىشوند. توجه بهمراتب مختلف سياستها، مىتواند نسبت سياستهاى كلان و خرد را مشخص كند. بلطورىكه از يكسو، ميزان تحقق و اجرايىشدن اهداف كلان و سياستهاى كلى نظام و از سوى ديخر، ميزان التزام يا نبود التزام سياستها و برنامهاى اجرايى نسبت به سياستهاى كلى را نشان مى دهد (به نقل از كاردوانى و همكاران، 90ب (1). لذا در ادامه، يافته هاى يُزوهش در راستاى ياسخ به سوال يزّوهش مبنى بر "ابيان ديدكاه رفاه خانواده در جمهورى اسلامى اير ان) مرور شدهاند. از تحليل و كدگذارى سياستهاى كلى و اجر ايى در سطوح بخشى و فرابخشى مقولمهاى زير به دست مى آيد:

ا. ارزشمندى و قداست خانواده: توجه به گستره اين مفهوم، تحقق حفظ و حراست از بنيان خانواده و تلاش براى پِيدارى آن را مىتوان هدفى كلان و معيار حاكم بر تمامى

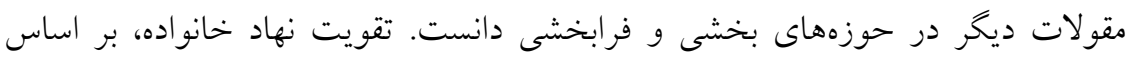
ضوابط اسلامى، از شاخصهايى است كه به صورت مكرر در سياستهاى كلى نظام بر آن تأكيد مىشود. بر اين مبنا، مفهوم تحكيم بنيان خانواده و حراست از آن در اكثر اين اسناد، 
جلو گيرى از فروياشى خانواده با طلاق را به تصوير مى كشد. هدف كلان كاهش طلاق در

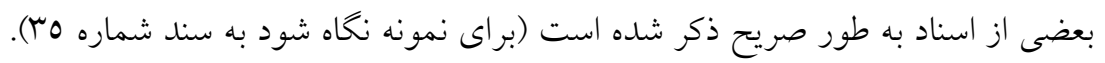

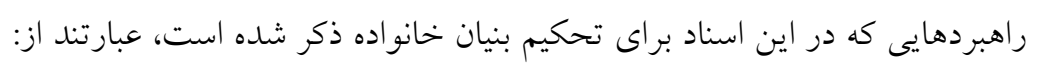

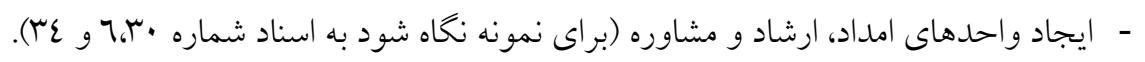

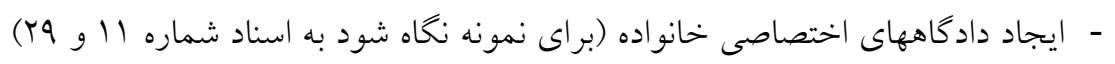

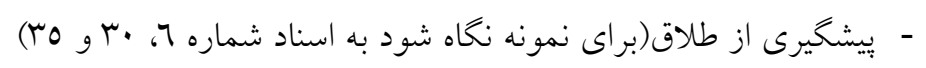

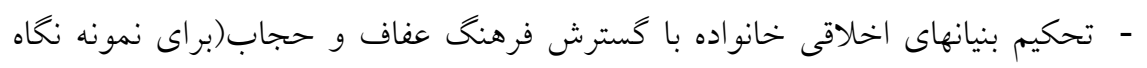

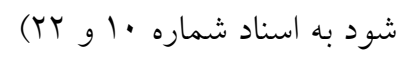

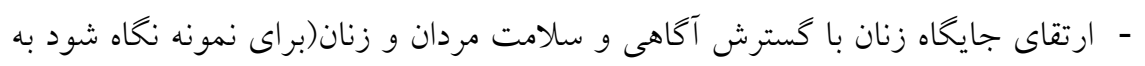

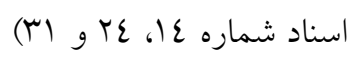
- - بهبود روابط بين اعضاء خانواده و تربيت فرزندان(براى نمونه نخاه شود به اسناد شماره (Y) g) Err.

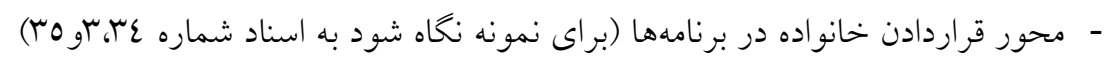

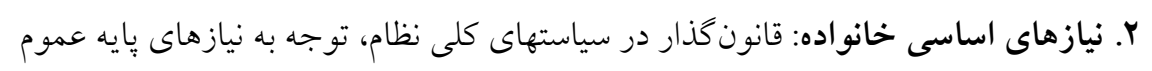

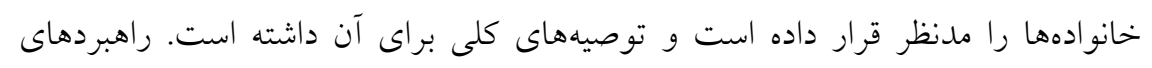

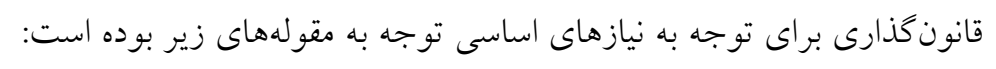

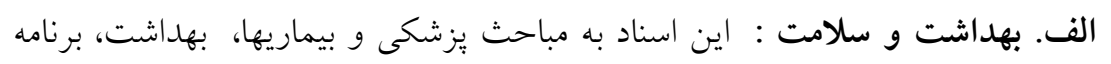

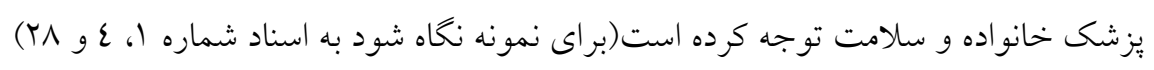

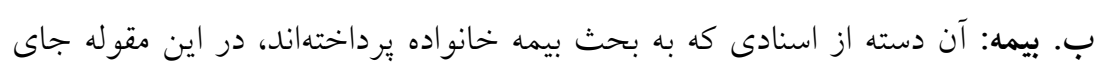

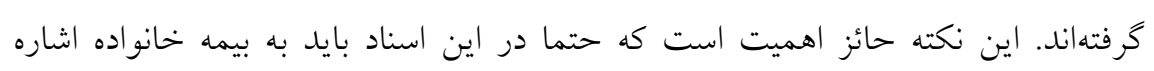

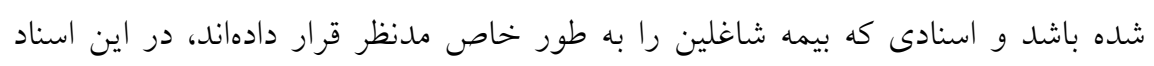


Social Welfare Quarterly, Vol 18, Fall 2018, No 70

موردبررسى قرار نخرفتهاند(براى نمونه نخاه شود به اسناد شماره Y و Y^). ج. مسكن: تأمين مسكن از ديخر نيازهاى اساسى است كه قانون كذار در بعضى از موارد به طور خاص تأمين و تسهيل آن را براى خانواده مورداشاره قرار داده است. تامين مسكن هم به طور كلى بهعنوان يك حق يايه مدنظر قرار گرفته است(براى نمونه نخاه شود به اسناد

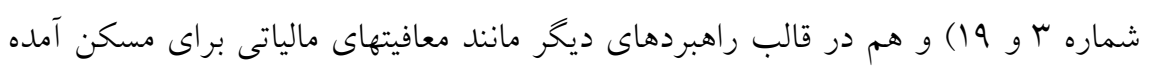

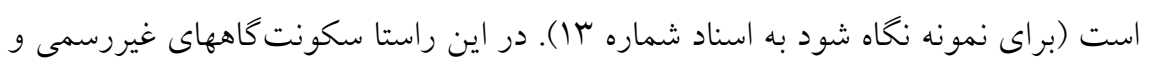

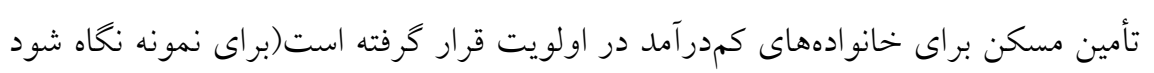
به اسناد شماره 19 و و (YV)

د. اقتصاد و درآمد: توجه به فقر خانواده از مقولههايى است كه در اسناد كلان مانند

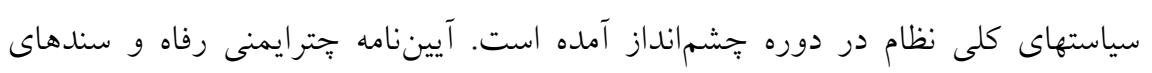
تحول اقتصادى هم به آن يرداخته است و در برنامه ششم هم با عنوان اقشار آسيبيذير دئي

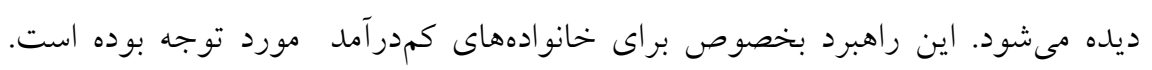
استراتزيهاى موجود در اسناد مربوطه نشانگر اين است كه يكى از اهداف طرح تحول اقتصادى و هدفمندسازى يارانهها، يرداخت يارانهها به سريرست خانوار است(براى نمونه

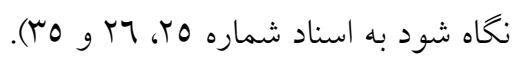
ه. امنيت: امنيت كليدوازهاى است كه گر جهه محدود و در لواى مباحث ديخر به كار رفته است اما در اسنادى جون سند جشمانداز، اهداف و اصول تشكيل خانواده و سياستهاى كلى

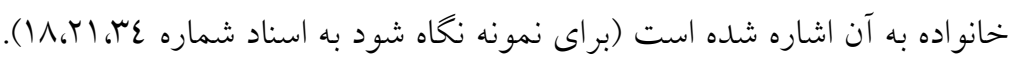

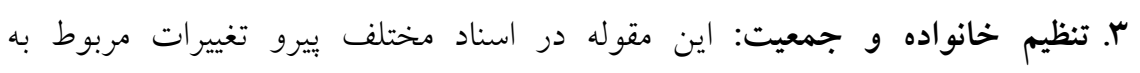
سياست گذارى در خصوص جمعيت متغير است و هم راهبردهاى كاهش و هم افزايش جمعيت را شامل مىشود. هدف اين اسناد در اولويت اول جمعيت است (براى نمونه نخاه

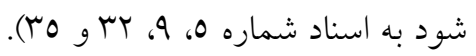


بررسى و تحليل سياستهاى اجتماعى جمهورى اسلامى ايران در حوزه رفاه خانواده نشان مى دهد كه به سياستهاى خانواده در اكثر اسناد به شكل ضمنى اشاره مىشود و صريح نيست. رفاه خانواده در اين اسناد در سه قالب كلى ارزشمندى و قداست خانواده، توجه به نيازهاى اساسى خانو اده و تنظيم خانو اده آمده است. در واقع مىتوان كفت سياستهاى رفاه خانو اده در اسنادى كه به عموم خانو ادهها توجه كرده كمتر صراحت دارد و در قالب توجه به نيازهايى مانند مسكن و درآمد و... مطرح شده است استو عدم صراحت در سياستهاى رفاه خانواده در كشورهايى كه از نظر اقتصادى سطح پايينترى دارند ديله مىشود (براى نمونه كشورهاى اكوادور و كلمبيا در كاريلو و همكاران، r r r ). حتى در بعضى از كشورها با سطح اقتصادى بالاتر نظير هلند نيز اين انتقاد وارد

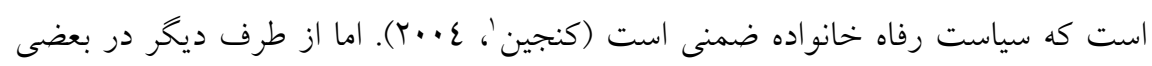

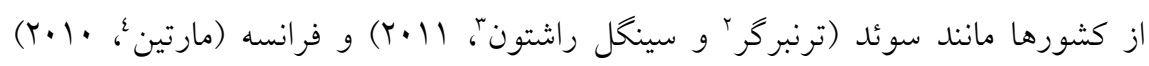
سياستهاى خانواده مشخص و صريح است و بخشى از برنامهاى آن كشور را به خود اختصاص مى دهد. همجنين در مطالعهاى هم كه در مورد سياست خانو اده كره جنوبى انجام شده، تصريح شده است كه اين كشور تا قبل از تغييرات ميانه دهه اول .... ميلادى جندان نخاه خانوادهمحورى در سياستخذارى حوزه رفاهى و مراقبت از كودى نداشته است و سياستهاى خانواده صريح نبودهاند اما يس از تغييرات اجتماعى و دمو گر افيك، سياستخذارى خانواده در اين كشور صريح، همخانى و با نخاهى بيشخيرانه شده است (جين و همكاران،

1. Knijn

3. Sigle-Rushton 
با اينكه در اسناد مرور شده، سياستها و قوانين مربوط به عموم خانوادهها استخراج شدهاند، اما در بسيارى از اين اسناد، نخاه به خانواده نخاهى فراگير نيست كه براى عموم خانوادهها سياست گذارى كند. در بسيارى از نيازهايى كه به آن يرداخته شده است، مانند مسكن و درآمد، كلماتى نظير اقشار آسيبٍٍير، فاقد درآمد و... ديده مىشود كه مىتوان نتيجه كرفت كه نخاه آسيبشناسانه و استحقاقسنج به رفاه خانواده در ايران وجود دارد. اين نخاه آسيبشناسانه و استحقاقسنج به رفاه خانو اده در بسيارى از كشورهاى ديخر هم ديده مىشود و مطالعات متعددى به آن اشاره كردهاند (براى نمونه كشورهاى اكوادور و كلمبيا

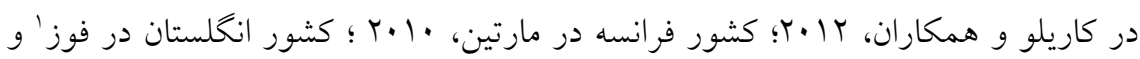

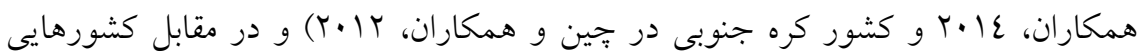
جون سوئد و اسلوونى ياستهايشان عمدتاً همشانى است (فوز و همكاران، عا • (T). در مطالعه كشورهاى كلمبيا و اكوادور تصريح شده است كه زمانى كه محدوديت منابع وجود دارد، سياستهاى متمركز بر خانواده بايد برنامههايى را در اولويت قراردهند كه براى خانوادههاى

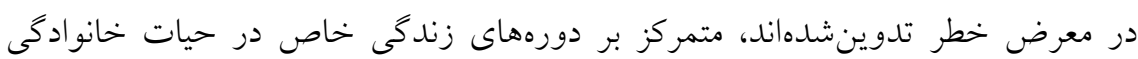
هستند(مانند والد شدن)، و جنبههايى از كاركرد خانو ادهها را تقويت مى كنند كه منابع بالقوه براى تابآورى محسوب مىشوند (كاريلو و همكاران، Y إب). با توجه به مطالعه صورت گرفته، به خانوادهمحور بودن برنامهها و سياستهاى اجرايى در اسناد محدودى (r سند) اشاره شده است كه با حجم اسنادى كه به قداست و ارزشمندى خانو اده( Tr سند) مى بردازد، برابرى نمى كند و همجينين راهكارى عملياتىشدن اين خانو اده محورى در اسناد مورداشاره واقع نشدهاند و در حد توصيههاى كلى و كلان باقى ماندهاند. همجنين به نظر مىرسد كه هدف حفظ و تداوم خانو اده، بيشتر هدفى جبرى است و در واقع به جاى اينكه بسترى براى يايدارى خانواده ايجاد شود، سعى بر حفظ و تداوم آن با ايجاد 
داد كاهها، مشاوره خانواده و ايجاد تسهيلات حقوقى شده است. در واقع كويا راهبردهايى كه براى حفظ و حراست از قداست خانواده بيشنهاد شدهاند، راهبردهايى كلان هستند كه لازم است در سطح ميانه و خرد، برنامهريزى و عملياتى شوند. بررسى اسنادى كه مربوط به تنظيم خانواده و جمعيت هستند، نشان مىدهد كه سياستها تابعى از سياستهاى جمعيتى هستند نه سياستهاى رفاه خانو اده. با توجه به اين تلاقى سياست خانواده با سياستهاى مرتبط با بارورى و جمعيت، در مطالعهاى (ماتسك و اوستنر'، ·. (Y) عنوان شده است كه در كشورهاى غربى ليبرال دموكرات كه سطح رفاهى بالايى دارند، سياست خانواده جهت گيرى در راستاى افزايش بارورى دارد كه هدف آنها صرفا آسايش نيست، بلكه اهداف سياسى و اقتصادى را بييخيرى مى كند و اين مباحث تاثير بسزايى در تغييرات سياست خانواده داشتهاند. آنجهه درنهايت از تحليل اسناد مربوط به رفاه خانواده بايد نتيجه كرفت اين است كه لازم

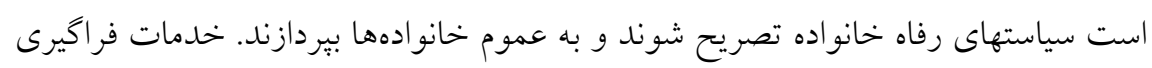

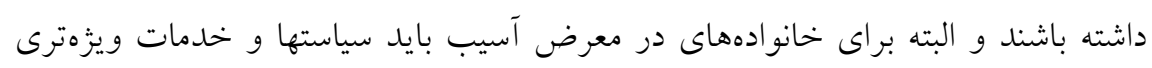

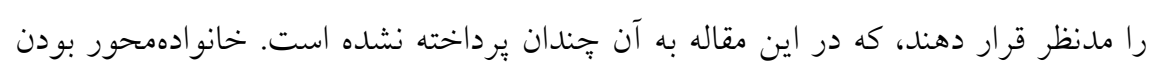
برنامهها مى تواند به كاهش مخاطرات خانو اده و حتى تأثيريذيرى خانو اده از سياستهاى ديخر مانند اقتصاد كمك كند.

1. Mätzke and Ostner 
- Adema, W. (2012). Setting the scene: The mix of family policy objectives and packages across the OECD. Children and Youth Services Review, 34(3), 487-498, doi: 10.1016/j.childyouth.2011.10.007

- Arshi, M. (2013). Purposing and Codifying Indexes of Family Welfare In order to Obtain and Confirming a Family Welfare Model in Iran. doctoral University of Social Welfare and Rehabilitation Sciences, Tehran, Iran. (700-205) (in Persian)

- Arshi, M., Takaffoli, M., \& Sabzi Khoshnam, M. (2015). Family Welfare Policies in Iran, Comparative Study of Development Programs. Socialworkmag, 4(1), 38-51. (in Persian)

- Bagheri, S. (2004). Family and social policy in the national and transnational arena. Women's Strategic Studies, 7(25), 152-179. (in Persian)

- Bogenschneider, K. (2006).Teaching Family Policy in Undergraduate and Graduate Classrooms: Why It's Important and How to Do It Better. Family Relations, 55 (January 2006), 16-28. Blackwell Publishing. National Council on Family Relations.

- Bogenschneider, K. (2014), Family Policy Matters: How Policymaking Affects Families and What Professionals Can Do, 3rd Edition, London: Routledge.

- Carrillo, S. Ripoll-Núñez, K., \& Schvaneveldt, P. L. (2012). Family Policy Initiatives in Latin America: The Case of Colombia and Ecuador. Journal of Child and Family Studies, 21(1), 75-87, doi: 10.1007/s10826011-9539-z

- Chin, M., Lee, J., Lee, S., Son, S., \& Sung, M. (2012). Family Policy in South Korea: Development, Current Status, and Challenges. Journal of Child and Family Studies, 21(1), 53-64, doi: 10.1007/s10826-011-9480-1

- Fagnani, J. (2012). Recent reforms in childcare and family policies in France and Germany: What was at stake? Children and Youth Services Review, 34(3), 509-516, doi: 10.1016/j.childyouth.2011.10.011

- Ferragina, E., \& Seeleib-Kaiser, M. (2015). Determinants of a Silent (R)evolution: Understanding the Expansion of Family Policy in Rich OECD Countries1. Social Politics: International Studies in Gender, State \& Society, 22(1), 1-37, doi: 10.1093/sp/jxu027

- Fosse, E., Bull, T., Burström, B., \& Fritzell, S. (2014). Family policy and inequalities in health in different welfare states. International Journal of Health Services, 44(2), 233-253, doi: 10.2190/HS.44.2.c 
- Ghiasvand, A.(2016). Analysis and Evaluation of Family Policies: With Emphasis on 'Shekofehaye Eshgh' Project. Biquarterly Journal of sociology of social institution. 3(7), 93-120. (in Persian)

- Hezar Jaribi, J. \& Safar Shali, R.(2012). Social welfare anatomy. Jamee and Farhang publication: Tehran. (in Persian)

- Human, H. A.(2006). Hanbook of Qualitative Research. Samt publication: Tehran. (in Persian)

- Human, H. A.(2006). Hanbook of Qualitative Research. Samt publication: Tehran. (in Persian)

- Jazayeri A, Salavati M. Social Policy and Family. Social Welfare. 2003; 3 (10) :233-244 (in Persian)

- Kardavani, R., Taj Mazinani, A. A., Mirkhani, E. \& Sajadi, S. M.(2016). Study of Employment Policy Strategies in the field of Motherhood in Islamic Republic of Iran. The quarterly journal of women and family socio cultural council. 18(72): 7-31 doi: 10.22095/jwss.2016.44412. (in Persian) - Knijn, T. (2004). Social and Family Policy, The Case of the Netherlands. Netherlands: Utrecht University.

- Logan, S. L. M. (2013). Family: Overview. Encyclopedia of Social Work. Updated on 03 Sep 2013. Available at: http://socialwork.oxfordre.com - Martin, C. (2010). The reframing of family policies in France: Processes and actors. Journal of European Social Policy, 20(5), 410-421, doi: $10.1177 / 0958928710380479$

- Mätzke, M., \& Ostner, I. (2010). Introduction: Change and continuity in recent family policies. Journal of European Social Policy, 20(5), 387398, doi: 10.1177/0958928710380476

- McCarthy, J. R. \& Edwards, R. (2011). The SAGE key Concepts Series: Key concepts in family studies London: SAGE Publications Ltd doi: 10.4135/9781446250990.(Translated in Persian by M. M. Labibi). (in Persian) - Mohaghegh Damad, M. and Afsari, H.(2015). Family Entry.The Great Islamic Encyclopedia. Center for the Great Islamic Encyclopedia. vol. 22, S. K. Musavi Bojnordi(Chief editor). Last update: 31.12.2016. Available at: https://www.cgie.org.ir (in Persian)

- Pinker, R. A. (2014). Britannica Encyclopedia. Last Updated 9-252014, Available at: http://www.britannica.com/.

- Rabe, M. (2017). Family policy for all South African families. International Social Work, 60(5), 1189-1200, doi: 10.1177/0020872816655866 
- Rafiey, H.(2000).Social welfare approaches. Social security quarterly: social security research institute. 2(5), 35-56. (in Persian)

- Scruggs, L. A. \& Allen, J. P. (2006). Social Stratification and Welfare Regimes for the 21 Century; Revisiting the" Tree Worlds of Welfare Capitalism". Paper prepared for delivery at the 15 th International Conference of Europeanists, drake hotel, Chicago, March 30, April 1.

- Seekings, J. (2005). The Politics of Welfare Regimes in the south. Paper to be presented at the Yale Conference on Distributive Politics, New Haven, April / May.

- Tunberger, P., \& Sigle-Rushton, W. (2011). Continuity and change in Swedish family policy reforms. Journal of European Social Policy, 21(3), 225-237, doi: 10.1177/0958928710395048.

- URL: http://refahj.uswr.ac.ir/article-1-1997-fa.html (in Persian)

- Yilmaz, Z. (2015). "Strengthening the Family" Policies in Turkey: Managing the Social Question and Armoring Conservative-Neoliberal Populism. Turkish Studies, 16(3), 371-390, doi: 10.1080/14683849.2015.1067863.

- Zaferanchi, L. (2006). Women and Family in Four Development Plans. Women's Strategic Studies, 9(33), 98-129. (in Persian) 